\title{
Bid'at, Custom and the Mutability of Legal Judgments: The Debate on the Congregational Performance of Supererogatory Prayers in the Seventeenth-Century Ottoman Empire
}

\section{Derin Terzioğlu}

"You want to get rid of all innovations whether they be good or bad. It is also an innovation to wear underpants. Will you also abolish them?" asked one of the refined ones, who had reservations about the [Kadızâdeli] sheikhs.

"Yes, we shall also abolish them. Let them wear waistcloths instead," answered Turk Ahmed.

"Eating with a spoon is also an innovation. What will you do about that?" asked the same man.

"We shall also abolish it. Let them eat with their hands. It is not poison! What harm will it do to have food smeared on their hands?"

The refined man was astounded and retorted with a laugh: "Now, effendis, you want to strip the people and dress them like barebottomed Bedouins!"

Another man in their company added: "O my sultan, how will spoon-makers make a living, if you forbid spoons?"

Turk Ahmed answered: "Let them make toothpicks and rosaries and make a living thus."

The refined man challenged Turk Ahmed: "If you have the Turks of Gerede and Taraklı make toothpicks and rosaries, then by what trade will the poor ones of the two holy sanctuaries [Mecca and Medina] support themselves?"1

1 Mustafa Naîmâ Efendi, Târih-i Na îmâ (Ravzatü'l-Hüseyn fî Hulâsati Ahbâri'l-Hâfikayn), edited by Mehmet İpşirli (Ankara: TTK, 2007), vol. 4, 1710. 
This humorous verbal exchange between a supporter and two critics of the Sunni revivalist movement of the Kadızâdelis reveals a central tension that underlay the seventeenth-century Ottoman debates on Islamic orthopraxy: Was it possible, or even desirable, to purge the living practice of Muslims of all bid'ats, innovations that had infiltrated it since the time of the Prophet? Could one pursue such a campaign oblivious of local customs or of social, political, and economic exigencies? Was the status of controversial practices to be determined by the yardstick of the 'ancients' (selef) alone, or could one also take into consideration the 'changing conditions of the times'?

While this chapter is concerned specifically with the ways Ottoman scholars grappled with these questions in the seventeenth century, the question of legal change has been raised by Muslims at multiple points in the course of history and it became particularly pertinent in the modern era. To understand these debates, it is essential to keep in mind that even although the word 'sharia' is commonly translated into English as 'Islamic law', it has historically been a broader concept signifying religious and moral as well as legal norms. As Baber Johansen has elucidated, in the premodern Hanafi jurisprudential tradition, the religious and moral norms comprised under the rubric of the sharia addressed relations between believers and God, and evaluated human behaviour from the perspective of 'religiosity' (diyāna), while the legal norms (ahkām, plural of hukm) regulated human relations in the here and now. The legal norms were concerned only with the external manifestations of human acts, while religious and moral norms also took into consideration questions of intention. Kadıs judged mainly in accordance with legal norms, whereas depending on the issue in question muftis had to juggle both sets of norms. Johansen has shown that throughout the history of Islamic religio-legal deliberation these two sets of norms coexisted in a state of dynamic (and sometimes tension-ridden) equilibrium until the attempts to broaden the scope of ahkām and to make legal judgments coterminous with 'religion and morality' in the late-eighteenth century. ${ }^{2}$ This chapter will show that some of these tensions were in fact already being played out in the debates about religious worship and social custom in the seventeenth-century Ottoman Empire.

2 Baber Johansen, "Die sündige, gesunde Amme: Moral und gesetzliche Bestimmung $(H u k m)$ im Islamischen Recht", in Baber Johansen, Contingency in a Sacred Law: Legal and Ethical Norms in the Muslim Figh (Leiden: Brill, 1999), 172-88; for a discussion of how earlier western scholarship has reckoned with the religious and ethical dimensions of the sharia, see also idem, "Introduction", ibid., 42-72. 
A second general point that needs to be made before going into the seventeenth-century debates concerns the mutability of Islamic legal judgments. As the voluminous scholarship on the history of Islamic law has amply demonstrated, the vast corpus of religio-legal deliberations known as the sharia came into being as a result of the intellectual efforts of generations of Muslim scholars, and continued to evolve in various ways after the 'formative period' of the Islamic jurisprudential tradition. Yet, because the sharia is, like all religiolegal traditions, conservative by definition, its practitioners have not always been able to recognize its mutability, but neither was it completely unrecognized. Recent scholarship has documented for us a number of instances in which premodern Muslim jurists recognized legal change as both a fact and a necessity, and expressed this insight with the words, "legal judgments change in accordance with the change of time." ${ }^{3}$ At the same time, however, pre-modern Muslim scholars wanted to limit the variability of legal judgments. It became the norm from the thirteenth century onwards for (Sunni) jurists to adhere to one of the four (Sunni) schools of law (mezheb). ${ }^{4}$ It was also around this time that scholars began to allude to the 'closing of the gates of ijtihad' or 'independent reasoning', though views on this matter have differed from mezheb to mezheb and within each mezheb. ${ }^{5}$

In the Hanafi legal school, which was the official school of law in the Ottoman Empire, adherence to mezheb consensus was particularly valued. Still, this did not prevent the Hanafi jurists in the Mamluk sultanate in the fifteenth century and in the Ottoman Empire in the sixteenth century from rethinking certain aspects of Hanafi jurisprudence to meet the changing needs

3 Kevin Reinhart, "When Women Went to Mosques: al-Aydini on the Duration of Assessments", in Muhammad Khalid Masud, Brinkley Messick and David S. Powers (eds) Islamic Legal Interpretation: Muftis and their Fatwas (Cambridge, MA: HUP, 1996), 116-28. See also Wael B. Hallaq, "The Jurisconsult, the Author-Jurist and Legal Change", in idem, Authority, Continuity and Change in Islamic Law (Cambridge: Cambridge University Press, 2001), 166; Marion Holmes Katz, "The 'Corruption of the Times' and the Mutability of the Shari'a", Cardozo Law Review 28 (1) 2006, 171-85.

4 On the formation and consolidation of the schools of law, see Mohammed Fadel, "The Social Logic of Taqlìd and the Rise of the Mukhtașar", ILS 3 (2) 1996, 193-233; Christopher Melchert, The Formation of the Sunni Schools of Law, gth-1oth Centuries CE (Leiden: Brill, 1997); Ahmed El Shamsy, The Canonization of Islamic Law: A Social and Intellectual History (New York: CUP, 2013).

5 Wael B. Hallaq, "Was the Gate of Ijtihad Closed?" IJMES 16 (1984), 3-41; idem, "From Fatwās to Furū': Growth and Change in Islamic Substantive Law", ILS 1(1) 1994, 29-65; idem, A History of Islamic Legal Theories (Cambridge: CuP, 1997), Chs 4 and 5; idem, "The Jurisconsult", 166-235. 
of the state as well as the wider public. ${ }^{6}$ In the Ottoman context, the political authorities also played an active role in this process both by promulgating new laws (kanun) and by setting up an imperial hierarchy of ulema. It was the top-ranking members of this newly established learned hierarchy, in turn, who reinterpreted Hanafi jurisprudential thought on such matters as the land tax and cash waqfs, and who, in cooperation with the political authorities, helped achieve a greater degree of harmony with the state laws and customs in the lands of Rum (Anatolia and the Balkans). ${ }^{7}$

Predictably, the Ottoman brand of Hanafism that was thus fashioned also had its critics. Dissenting voices were heard particularly among the non-state appointed scholars in the former Mamluk provinces, ${ }^{8}$ but they were not absent among the state-appointed scholars in the core lands of the Ottoman Empire, either. The Rumi scholars who questioned the compatibility of time-honoured practices of Ottoman Muslims with Islamic law included even a one-time

6 Baber Johansen, Islamic Law on Land Tax and Rent: The Peasants' Loss of Property Rights as Interpreted in the Hanafite Legal Literature of the Mamluk and Ottoman Periods (London: Croom Helm, 1988); idem, "Legal Literature, and the Problem of Change: The Case of the Land Rent", in Johansen, Contingency, 446-64; and Martha Mundy and Richard Saumarez Smith, Governing Property, Making the Modern State: Law, Administration and Production in Ottoman Syria (London: I. B. Tauris, 2007).

7 On the developments in Hanafi law in the early modern Ottoman context, see, in addition to the sources cited in fn.6, Guy Burak, "Faith, Law and Empire in the Ottoman Age of Confessionalization (Fifteenth-Seventeenth Centuries), The Case of 'Renewal of Faith", Mediterranean Historical Review 28 (1) 2013, 1-23; and idem, The Second Formation of Islamic Law: The Hanafi School in the Early Modern Ottoman Empire (Cambridge: CUP, 2015); Snjezana Buzov, "The Lawgiver and His Lawmakers: The Role of Legal Discourse in the Change of Ottoman Legal Culture", Ph.D. dissertation (Chicago University, 2005); Hülya Canbakal, "Vows as Contract in Ottoman Public Life (17th-18th Centuries)", ILS 18 (1) 2011, 85-115; Haim Gerber, State, Society, and Law in Islam: Ottoman Law in Comparative Perspective (Albany: sunY, 1994); Colin Imber, Ebu's-Su'ud: The Islamic Legal Tradition (Stanford: suP, 1997); Jon E. Mandaville, "Usurious Piety in the Ottoman Empire: The Cash Waqf Controversy", IJMES 10 (1979), 289-308.

8 While scholars have mostly dwelled on the tensions between the Rumi and Arab ulema, some recent scholars have presented a more nuanced view. For the first approach, see Reem Meshal, "Antagonistic Sharī'as and the Construction of Orthodoxy in Sixteenth-Century Ottoman Cairo", JIS 21 (2) 2010, 183-212; Abdul Karim Rafeq, "The Syrian 'Ulamä’, Ottoman Law, and Islamic Sharī'a", Turcica 26 (1994), 9-32; idem, "The Opposition of the Azhar 'Ulamā' to Ottoman Laws and its Significance in the History of Ottoman Egypt", in Brigitte Marino (ed.) Études sur les villes du Proche-Orient XVI e et XIX e siècle: Hommage à André Raymond, (Damascus: Institut français d'études arabes de Damas, 2001), 43-54; for more nuanced treatments, see Burak, Second Formation, especially chapters 3-5; and Helen Pfeifer, "Encounter After the Conquest: Scholarly Gatherings in 16th-century Ottoman Damascus", IJMES 47 (2015), 219-39. 
şeyhülislâm, Çivizâde Muhyiddin Mehmed Efendi (d.1547), but perhaps the most influential of the Rumi critics over the long run was the more modestly ranked Birgivî Mehmed Efendi (d.1573), who, from his post as müderris in the small town of Birgi in western Anatolia, boldly challenged the opinions of the influential Şeyhülislâm Ebüssuûd (d.1574) on such issues as the legal status of cash waqfs, payment for religious services and land ownership. ${ }^{9}$

Yet, it was only in the seventeenth century that this internal critique of the Ottoman Sunni-Hanafi orthopraxy found greater support. This was, significantly, a time of crisis for the Ottoman state, shaking the confidence of many in the existing order, and increasing inter-elite competition and conflict. It was also a time when both the Ottomanization of the Arab provinces and the Sunnitization of the lands of Rum reached a certain level of maturity, and when intellectual exchange between scholars in different regions became greater. All these developments created a fertile ground for the outbreak of a series of new debates about Sunni-Hanafi orthopraxy in the Ottoman Empire.

One of the distinguishing features of the seventeenth-century debates was that they were no longer confined to the mevâli, the fully-fledged scholars who served as müderrises and müftis, but were also overtaken and popularized by the meşâyih, Sufi and non-Sufi mosque preachers. One such preacher was Kadızâde Mehmed Efendi of Balıkesir (d.1635), who was a student of a student of Birgivî Mehmed Efendi and who later gave his name to the Kadızâdeli movement. The Kadızâdeli preachers used their sermons and public lectures to mobilize the ordinary men and ruling powers alike to 'command the right and forbid the wrong' (emr bi'l-ma' rûf ve nehy 'an il-münker) and to put an end to the 'blameworthy innovations' that were rampant in Ottoman lands. The practices they targeted as bid'at covered a wide range from coffee, coffeehouses and smoking to the use of ritual music and dance at Sufi gatherings, and from

9 Mehmet Gel, "XVI. Yüzyılın İlk Yarısında Osmanlı Toplumunun Dinî Meselelerine Muhalif Bir Yaklaşım: Şeyhülislam Çivizâde Muhyiddin Mehmed Efendi ve Fikirleri Üzerine Bir İnceleme", Ph.D. thesis (Gazi Üniversitesi, 2010); Katharina Anna Ivanyi, "Virtue, Piety and the Law: A Study of Birgivī Mehmed Efendi's al-Ṭarīgat al-Muhammadiyya", Ph.D. dissertation (Princeton University, 2012); idem, "And the Question of Lands is Very Confusing': Birgivî Mehmed Efendi (d.981/1573) on Land Tenure and Taxation", in Marinos Sariyannis (ed.) Political Thought and Practice in the Ottoman Empire, Halcyon Days in Crete IX, a symposium held in Rethymno, 9-11 January 2015 (Rethymno: Crete University Press, 2019), 137-47; Ahmet Kayl, "A Critical Study of Birgivî Mehmed Efendi's Works and Their Dissemination in Manuscript Form” (MA thesis, Boğaziçi Üniversitesi, 2010); Mandaville, "Usurious Piety"; Huriye Martı, Birgivî Mehmed Efendi (Ankara: Türkiye Diyanet Vakfı Yayınları, 20o8); Emrullah Yüksel, Mehmed Birgivînin (929-981/1523-1573) Dinı̂ ve Siyasî Görüşleri (Ankara: Türkiye Diyanet Vakfı Yayınları, 2011). 
asking for intercession at the tombs of the saints to the melodic recitation of the Quran and ezân.

In the secondary literature, the Kadızâdelis have been characterized variously as 'Sunni revivalists', 'fundamentalists', 'Muslim puritans', and 'salafis' avant la lettre. ${ }^{10}$ As scholars have looked more closely at the religio-legal literature of the time, however, it has become clear that the Kadizâdelis actually shared a lot with other members of the Ottoman learned establishment and the learned Sufis, who often opposed them. We now know, for instance, that far from being crypto-Hanbalis, the Kadızâdeli leaders were just as deeply steeped in the Hanafi tradition as their adversaries..$^{11}$ But this realization has also come

10 Marc David Baer, Honored by the Glory of Islam: Conversion and Conquest in Ottoman Europe (Oxford: OUP, 2008); Michael Cook, Commanding Right and Forbidding Wrong in Islamic Thought (Cambridge: CUP, 200o), 323-30; Semiramis Çavuşoğlu, "The Kāạīzādeli Movement: An Attempt of Şerī'at-minded Reform in the Ottoman Empire", Ph.D. dissertation (Princeton University, 199o); Ahmet Yaşar Ocak, "XVII. Yüzyllda Osmanlı İmparatorluğu’nda Dinde Tasfiye (Püritanizm) Teşebbüslerine Bir Bakış: Kadızadeliler Hareketi", Türk Kültürü Araştırmaları 1-2 (1983), 208-225; Marinos Sariyannis, "The Kadızadeli Movement as a Social Phenomenon: The Rise of a 'Mercantile Ethic'?" in Antonis Anastasopoulos (ed.) Political Initiatives 'from the Bottom up' in the Ottoman Empire, Halcyon Days in Crete VII, 9-11 Jan. 2009. Rethymno: Crete University Press, 2012, 263-89; E. Ekin Tuşalp Atiyas, "The 'Sunna-Minded' Trend", in Marinos Sariyannis (ed.) A History of Ottoman Political Thought up to the Early Nineteenth Century (Leiden, Boston: Brill, 2019), 233-78; Madeline C. Zilfi, "The Kadızadelis: Discordant Revivalism in Seventeenth-Century Istanbul", Journal of Near Eastern Studies 4 (1986), 251-71; idem, The Politics of Piety: The Ottoman Ulema in the Postclassical Age (1600-1800) (Minneapolis: Bibliotheca Islamica, 1988).

11 On the Hanafi framework of Birgivî and his Kadızâdeli followers, see Ivanyi, "Virtue, Piety and the Law", 76-82; Ömer Faruk Köse, "The Fatwa Collection of an Ottoman Provincial Mufti, Vani Mehmed Efendi (d.1685)" (MA thesis, Boğaziçi Üniversitesi, 2015), Chapter 3; Bernd Radtke, "Birgiwīs Ṭarīqa Muḥammadiyya: Einige Bemerkungen und Überlegungen", JTS 26 (1) 2002. This same article also appears in Jan Schmidt (ed.), Essays in Honour of Barbara Flemming (Cambridge, MA: Department of Near Eastern Languages and Civilizations, Harvard University, 2002), 159-74; Khaled El-Rouayheb, "From Ibn Hajar al-Haytamī (d.1566) to Khayr al-Dīn al-Ālūsī (d.1899): Changing Views of Ibn Taymiyya amongst Sunni Islamic Scholars", in S. Ahmed and Y. Rapoport (eds), Ibn Taymiyya and His Times (Oxford: OUP, 2010), 303-5. For scholars who continue to see the influence of Ibn Taymiyya in the writings of some Kadızâdelis, see Yahya Michot's Introduction to Ahmed el-Akhisari, Against Smoking: An Ottoman Manifesto, edited and translated byYahya Michot (Leicestershire: Kube Publishing: 2010); Mustapha Sheikh, Ottoman Puritanism and its Discontents: Aḥmad al-Rūmī al-Aqḥișārī and the Qādizādelis (Oxford: OUP, 2016); idem, "Taymiyyan Influences in an Ottoman-Hanafì Milieu: The Case of Ahmad al-Rumī al-Aqhișārī", The Royal Asiatic Society 3 (2014), 1-20. For a reconsideration of the question of Taymiyyan influences in the early modern Ottoman context, see Caterina Bori, "Transregional Spaces of Reading and Reception", The Muslim World, 108 (1) 2018, 87-123; Derin Terzioğlu, "Ibn Taymiyya, al-Siyāsa al-Shar'iyya and the Early Modern Ottomans", in 
at the cost of obscuring what it was that set the Kadızâdelis apart. It has also led to a new tendency to downplay the doctrinal differences between the contending sides and to privilege instead the social and professional animosities that propelled the conflict. Ultimately, however, what needs to be done is to analyse the debates both doctrinally and contextually. What was it that led the Kadızâdeli preachers to oppose certain changes in the practices of Muslims, and not others? What was it that led their critics to come to the defence of some of these changes, and not others?

This chapter suggests some partial answers to these questions in the context of the debate on the congregational performance of supererogatory prayers, and particularly the popular nocturnal prayers of Raghāib, Barāat and Qadr. Although this was one of some two dozen items of debate between the Kadızâdelis and their adversaries, it has not attracted much attention until now. This is, in a sense, understandable, for unlike coffee, coffeehouses and smoking, which had been introduced to the Ottoman capital in the midsixteenth and early-seventeenth centuries respectively, ${ }^{12}$ the congregational performance of supererogatory prayers was a long-standing 'innovation'. The popular Raghā’ib, Barāat and Qadr prayers had been around for centuries, and were seen by many to be an integral part of Islamic piety. But this is also what makes the debate about them particularly interesting and potentially even more revealing about the competing understandings of Islamic law and piety, and normative change in the seventeenth-century Ottoman Empire.

\section{Debate on the Congregational Performance of the Raghāib, Barāat and Qadr Prayers}

To a modern, secular observer, a debate about whether or not to perform supererogatory prayers in congregation might not seem like a weighty issue that merits much attention. Yet, this was actually one of the more divisive issues

Tijana Krstić and Derin Terzioğlu (eds). Historicizing Sunni Islam in the Ottoman Empire, c.1450-c.1750 (Leiden: Brill, 2020).

12 On coffee, coffeehouses and smoking as well as the religio-legal debates about them, see James Grehan, "Smoking and 'Early Modern' Sociability: The Great Tobacco Debate in the Ottoman Middle East (Seventeenth to Eighteenth Centuries)", American Historical Review 111 (December 2006), 1352-77; Ralph Hattox, Coffee and Coffeehouses: The Origins of a Social Beverage in the Medieval Near East (Seattle: University of Washington Press, 1985); Cemal Kafadar, "How Dark is the History of the Night, How Black the Coffee and How Bitter the Tale of Love: The Measure of Leisure and Pleasure in Early Modern Istanbul", in Arzu Öztürkmen and Evelyn Birge Vitz (eds), Medieval and Early Modern Performance in the Eastern Mediterranean (Turnhout: Brepols, 2014), 243-69. 
being debated by Muslims in the seventeenth century. Writing around 1656 , the Ottoman bureaucrat and intellectual Kâtib Çelebi described with clear disapproval how some fanatical men sometimes walked out on the congregation in protest at the communal performance of the nocturnal supererogatory prayers. ${ }^{13}$ But walking out on the congregation was still a mild reaction, considering that in 1703 madrasa students opposed to the practice physically attacked the people who performed the popular Qadr prayer in congregation in the Ulucami (Great Mosque) in Bursa, killing one and wounding several. The incident prompted a hastily summoned court case, the execution and banishment of a few of the perpetrators and heated discussion about the whole affair for long afterwards. ${ }^{14}$

Why did this issue provoke such strong feelings among Ottoman Muslims at the time? What was at stake in the debates about the congregational performance of supererogatory prayers? To answer these questions, it is first necessary to review some basic information about the legal stipulations concerning ritual worship. According to all four Sunni mezhebs, the primary obligatory prayers for Muslims are the five daily prayers, whereas supererogatory prayers (näfila, plural nawäfil) are those extra prayers that they may perform either before or after the obligatory prayers. The latter should be undertaken on a voluntary basis and out of devotion to God. While the religious authorities thought that such voluntary acts of piety were, in principle, good, they also wanted to distinguish them clearly from obligatory acts of worship. They worried that ordinary Muslims could mistakenly believe these supererogatory prayers to be obligatory, or else engage in them to show off their piety rather than to perfect their devotion to God. Hence, the insistence of most early authorities that Muslims perform supererogatory prayers in the privacy of their homes rather than in congregation in mosques. An exception was made only for those prayers that were considered sunna mu'akkada, that is sanctioned by

\footnotetext{
13 Katib Çelebi, The Balance of Truth, translated with an Introduction and Notes by G. L. Lewis (London: George Allen and Unwin Ltd, 1957), 98-9.

14 The incident is reported in a slightly different way in two different hagiographical accounts covering the lives and deeds of the dervishes of the Misrî branch of the Halvetî tarikat Gazzîzâde 'Abdüllatif, Menâkıb-ı Gazzî, fol. 57a-59a, MS 1042, Orhan, Bursa Eski Yazma ve Basma Eserler Kütüphanesi; and Râkım İbrahim, Vâkı ât-ı Pîr-i Rûşen, 17-18, Ms 79o, İzmir, $\mathrm{sK}$. The attack and the subsequent court course case are also discussed in several different works by the Celveti sheikh İsmâil Hakkı Bursevî (d.1725). See İsmâil Hakkı Bursevî, Kitâbü'n-Netîce: Bursevînin Vâridatı ve Şerhleri, edited by Ali Namlı (Istanbul: TYEквY, 2019), 743; İhsan Kara, "İsmail Hakkı Bursevi'nin Tuhfe-i Hasekiyyesi (3. Bölüm)", MA thesis (Marmara Üniversitesi, 1997), 135; Ali Naml, İsmâil Hakkı Bursevî: Hayatı, Eserleri, Tarikat Anlayışı (Istanbul: İnsan Yayınları, 2001), 79-81.
} 
the Prophet's own example, such as the tarāwīkh prayers performed during the nights of Ramadan. ${ }^{15}$ The latter could be performed in congregation, just like the five daily prayers, the prayers of the two canonical religious festivals ('id al-fitr and i $\bar{i}$ al-adhā $)$ as well as a few other special prayers, such as the funeral prayer, the prayer of the eclipse, and the prayer for rainfall. ${ }^{16}$

As might be expected, the actual practices of ordinary believers did not always fit the prescriptive framework of the early authorities. Indeed, a series of new public forms of supererogatory worship sprang up in the course of the ninth, tenth and eleventh centuries along with a whole lore of stories and traditions that invested the corresponding days in the Islamic calendar with liturgical significance. The first of these days in the Islamic calendar was the twelfth day of the month of Rabī' al-awwal, celebrated as the birthday (Mawlid) of the Prophet Muhammad. Then came the Night of Raghāib, or Benefits, which fell on the first Friday of the month of Rajab, and which was widely believed to be the night on which the Prophet was conceived. The 27th night in the month of Rajab was celebrated as the Night of Mirrāj, or Ascension, on which Muhammad was believed to have undertaken a nightly journey from Mecca to Jerusalem and ascended to Heaven. The Night of Baräat, or Forgiveness, on which God was believed to forgive a great number of sinners, was associated with the night preceding the fifteenth day of the month of Shabān. Last but not least, the twenty-seventh night of the month of Ramadan was celebrated as the Night of Power (laylat al-Qadr), which is mentioned in the ninety-seventh chapter of the Quran, though without associating it with a particular date, as the night on which the Quran was revealed (97:1), and as being "more auspicious than a thousand months" (97:3).

The introduction and popularization of a plethora of commemorative practices on the above-mentioned days took place by popular demand as well as with the support of the political authorities. As for the religious authorities, they widely conceded that the celebrations in question were, as we might say, 'invented traditions', but while some vehemently opposed them as 'reprehensible innovations' (bid'a makrüha), others were willing to accommodate them as 'good' or 'permissible innovations' (bid'a hasana), and yet others tried to set some limits on the kinds of celebration and worship that people undertook on these occasions. The debates about these practices were particularly heated in

\footnotetext{
15 Some present-day salafis also question the sunna mu'akkada status of the taräwïk prayers and object to their congregational performance.

16 For an overview of Islamic strictures on canonical ritual prayer, see Marion Holmes Katz, Prayer in Islamic Thought and Practice (Cambridge: CUP, 2013).
} 
Ayyubid and Mamluk Syria, where critics were bothered by the resemblances between these commemorative practices and those of Shiites and Christians on their own holy days. The critics also maintained that investing specific days of the calendar with religious significance in the absence of Prophetic sanction was a particularly dangerous form of innovation, as ordinary believers commonly mistook the performance of supererogatory forms of worship on these occasions to be a 'shortcut to salvation'. People who participated enthusiastically in these public celebrations, it was argued, were often lax or negligent about observing their daily obligatory prayers and other forms of canonical worship. ${ }^{17}$

It must be remarked, however, that scholars did not oppose all these 'innovations' with equal vehemence. Among the five non-canonical nocturnal public celebrations described above, the celebration of Mawlid, the Prophet's birthday, was considered less objectionable as "it was based not on blatantly spurious hadith but on a historical event of widely accepted religious significance."18 Scholarly opinion was similarly more favourable about the commemoration of the Prophetic Ascension. By contrast, a good deal of polemic revolved around the congregational performance of supererogatory prayers on the nights of Raghāib, Barāat and Qadr, ${ }^{19}$ which would also be the main item contested by seventeenth-century Ottoman scholars.

Even though a detailed study of the spread of these popular celebrations in Anatolia and the Balkans is still a desideratum, the available evidence indicates that Rumi Muslims also honoured these five nights with a variety of supererogatory acts of worship from at least the fourteenth century onwards. ${ }^{20}$ As for the

17 On the popular practices conducted on the five 'meritorious' days and the religio-legal debates about them in the medieval Islamic context, see Marion Holmes Katz, The Birth of the Prophet Muhammad: Devotional Piety in Sunni Islam (Abingdon: Routledge, 2007), especially 143-68; Daniella Talmon-Heller, Islamic Piety in Medieval Syria: Mosques, Sermons and Cemeteries under the Zangids and Ayyūbids (1146-1260) (Leiden: Brill, 2007), 61-6; Daniella Talmon-Heller and Raquel Ukeles, "The Lure of a Controversial Prayer: Șalāt al-Raghāib (The Prayer of Great Rewards) in Medieval Arabic Texts and from a Socio-Legal Perspective", Der Islam 89 (2) 2012, 141-66.

18 Katz, The Birth of the Prophet, 153. See also Jonathan Brown, "Even If It's Not True It's True: Using Unreliable Hadìths in Sunni Islam”, ILS 18 (2011), 21-3.

19 Katz, The Birth of the Prophet, 153.

20 An early reference to the celebration of the Prophet's birthday and the 'blessed nights in the three months' (namely the months of Rajab, Sha'bān and Ramadan) in the Rum geography comes up in the 1323 endowment deed of Asporça Hatun, the Greek-born wife of the second Ottoman ruler Orhan. The original deed, however, is not extant. What we have at hand is a copy made in 1555 from the original in the kadı court of Bursa. For the facsimile, Arabic transcription and (a rather loosely made) Turkish translation of this copy, 
performance of supererogatory prayers in congregation, the practice seems to have been so well established among Rumi Muslims that in the fifteenth and sixteenth centuries the non-canonical congregations on the nights of Raghäib, Barāat and Qadr were often mentioned in the same breath as the congregations for the canonical prayers. For instance, the vakfyye of Karamanoğlu Ali Bey, drafted in 1415, asks that the imam of his newly founded madrasa in Niğde lead not just the five daily prayers but also the Raghāìb, Barāat, tarāwìkh and Qadr prayers 'in congregation according to Islamic custom. ${ }^{21}$ Likewise, in both the late-fifteenth and late-sixteenth-century copies of the endowment deed of Mehmed II, the responsibility of the imams of the mosque of Mehmed II was defined as leading the congregation during "the five obligatory daily prayers, the tarāwīkh prayers, the prayer of the night of Raghāib and other prayers similar to these that are performed in congregation." ${ }^{22}$ It is worth stressing that madrasa-trained religious experts were involved in the preparation of these endowment deeds. Clearly, not just the common folk or laymen at large, but also a broad cross-section of the ulema viewed the popular nocturnal prayers as part of canonical worship in the lands of Rum.

The widespread acceptance of the congregational performance of supererogatory prayers among the Rumi ulema of the fifteenth and sixteenth centuries is perhaps not that surprising, considering that the vast majority of them were Hanafis, who were known for their more accommodating stance towards popular customs. However, not all the Hanafi authorities were comfortable with the congregational performance of supererogatory prayers. One Hanafi authority who had raised his voice against the practice at a fairly early point

see Sezai Sevim and Hasan Basri Öcalan (eds), Osmanlı Kuruluş Dönemi Bursa Vakfiyeleri (Bursa: Osmangazi Belediyesi, 2010). For articles that provide glimpses into the Ottoman celebrations of the said five nights, see Halide Aslan, "Osmanlı İmparatorluğu'nda Mübarek Gün ve Gecelerden Kandiller”, İslam San'at, Tarih, Edebiyat ve Mûsikîsi Dergisi 7 (13) 20o9, 199-231; M. Tayyib Okic, "Çeşitli Dillerde Mevlitler ve Süleyman Çelebi 'nin Mevlid'inin Çevirileri”, Atatürk Üniversitesi İlahiyat Fakültesi Dergisi 1 (1976), 17-78.

For the Arabic text, its Turkish translation and facsimile, see İsmail Hakkı Uzunçarşıll, “Niğde’de Karamanoğlu Ali Bey Vakfiyesi”, Vakıflar Dergisi 2 (1942), 45-69, especially 51. It is worth emphasizing that the endowment deed has come down to our time in the originally drafted 1415 version.

For a copy of the Arabic endowment deed, dated 1496, see Tahsin Öz (ed.), Zwei Stiftungsurkunden des Sultans Mehmed II. Fatih (Istanbul: Devlet Matbaası, 1935), 113-14; for a copy drawn up in Turkish in the late-sixteenth century copy, see [Mehmed II, 'Fatih'], Fatih Sultan Mehmet Vakfiyeleri (Istanbul: T. C. Başbakanlık Vakıflar Genel Müdürlüğü, 2003), 249-5o. For the dating of the endowment deed and its variant versions, see Çiğdem Kafescioğlu, Constantinopolis/Istanbul: Cultural Encounter, Imperial Vision, and the Construction of the Ottoman Capital (University Park, PA: PSU Press, 2009), 243-4, fn.118. 
was the Khwarezmian scholar Ibn al-Bazzāzī (d.1424), who was also widely known and respected in the Ottoman lands. In fact, it was by citing Bazzāzī that the Aleppan-born Ottoman Hanafi scholar İbrahim Halabī (d.1549) refuted the legitimacy of the same prayers in the long version of his manual on ritual ablution and prayer titled Ghunyat al-Mutamalli (Companion for the Worshipper), also known as Halabī Kabìr (The Long Halabī). Possibly, however, Halabì did not feel he had much of a chance of winning this battle, as he concluded his refutation with the remark, "the majority of the common people in Rum believe that these prayers are obligatory, and do not abandon them even when they abandon their obligatory prayers."23 This might explain why he did not include this polemical discussion in the shorter, and by all indications more popular, version of his manual, Mukhtașaru Ghunyat al-Mutamalli (The Abbreviated Companion for the Worshipper), also known as Halabi Șaghīr (The Short Halabī). Instead, he simply pointed out that it was 'better' to perform supererogatory prayers other than tarāwīkh and tahiyyat al-masjid in the privacy of one's home rather than in congregation. ${ }^{24}$

It seems, however, that Halabī was not alone in trying to dissuade Rumi Muslims from performing these nocturnal prayers in congregation. Between the years 1526 and 1534, the şeyhülislâm Ibn Kemal (d.1534) also issued several fatwas against the congregational performance of the nocturnal prayers of Raghāib, Barāat and Qadr. From one of these fatwas we learn that a scholar generically identified as 'Zeyd the scholar' (perhaps Halabī?) had read out the şeyhülislâm's fatwa against the practice from the pulpits of mosques; as a result, 'most imams' had ceased to perform these prayers in mosques, but 'some other imams' had not. It seems, however, that Ibn Kemal was unwilling to push the matter further, because when asked what to do about the non-conforming imams, he merely stated that 'they become sinners' (âsim olurlar). ${ }^{25}$

In any case, by the mid-sixteenth century, the Ottoman learned establishment had overcome its short-lived aversion to this long-standing innovation. When Ebüssuûd became şeyhülislâm in 1545, he defended the congregational

23 İbrahim Ḥalabī, Halabī Kabīr (Istanbul: Arif Efendi Matbaası, 1325/1907-8), 432-4.

24 İbrahim Ḥalabī, Tam Kayıtlı Haleb̂̀-i Sagîr ve Tercemesi (Taharet ve Namaz Bölümleri), translated by Hasan Ege (Istanbul: Salah Bilici Kitabevi, 1982), 237-8.

25 For variant copies of these fatwas, see İbn Kemal, Fetava, Ms. 118, fol. 5b-6a, Darülmesnevi, SK; MS. 1967, fol. 119b-120a, Nuruosmaniye; Nushî el-Nâsıhi/Mustafa b. Hamza b. İbrahim b. Veliyüddin. al-Hayāt Sharh Shurūt al-Ṣalät, Ms 971, fol. 3b, Carullah, sk. The fatwas are also cited in İbn Kemal, Şeyhülislâm İbn Kemal'in Fetvaları Işı̆̆ında Kanûnî Devrinde Osmanlı'da Hukukî Hayat, edited by Ahmet İnanır (Istanbul: Osmanlı Araştırmaları Vakfı, 2011), 56 . 
performance of supererogatory prayers on the nights of Raghāib, Barāat and Qadr in multiple fatwas. His rationale was that these prayers were simply too popular to be prohibited: 'the people at large honour' (âmme-i nâsın itibarları vardır) the congregational performance of supererogatory prayers on the nights of Raghā’ib, Barāat and Qadr; therefore, 'it is not permissible to prohibit them', the şeyhülislâm ruled. Interestingly, his only caveat was that the imam should not keep the communal performance of the supererogatory tasbih prayer excessively long, and unduly burden the congregation. ${ }^{26}$

Of course, the Sunna-minded criticisms directed at the congregational performance of these nocturnal prayers continued despite Ebüssuûd's defence of the practice. In his Jalä' al-Qulüb, completed in ${ }^{1564}$, the şeyhülislâm's foremost critic, Birgivî Mehmed Efendi, condemned those who persist in the performance of the Raghāìb, Barāat and Qadr prayers, 'especially in congregation', and pointed out that such scholars as Ibn al-Jawzī (d.1201) and Ibn al-Bawwāb (?) had revealed these prayers to be based on spurious hadiths. ${ }^{27}$ In his al-Tarīqat al-Muhammadiyya, written in 1572, Birgivî further stressed that innovations in worship come right after innovations in belief in their level of harmfulness and he urged Muslims to perform their canonical forms of worship in public while keeping their supererogatory acts of worship private. He did not, however, explicitly mention the congregational performance of the Raghāib, Barāat and Qadr prayers in this specific instance. ${ }^{28} \mathrm{All}$ in all, his position on these prayers can be said to have been clearly critical but also devoid of excessive polemical overtones.

Evidence indicates that the objections to the congregational performance of these prayers assumed a new urgency after the celebration of the five 'blessed nights' - Mawlid, Raghā’ib, Mi'rāj, Barāaat and Qadr - was given new imperial sanction, and as a result became both more ostentatious and more institutionalized in the late-sixteenth century. While I have been unable to ascertain the factual basis of the traditions that ascribe a leading role to Selim II (r.1566-74)

26 Ebussuûd, Şeyhülislâm Ebussuûd Efendi Fetvaları Işı̆̆ında 16. Asır Türk Hayatı, edited by Ertuğrul Düzdağ (Istanbul: Enderun Kitabevi, 1983), 61, fatwas numbered 201 and 202.

27 Birgivî Mehmed, Jalä’ al-Qulūb, edited by 'Āmir Sa'īd al-Zībārī (Beirut, 1995), 64. I thank Evren Sünnetçioğlu for directing me to this passage.

28 For a succinct discussion of Birgivî's views on this matter as he lays them out in his al-Taríqat al-Muhammadiyya, see Ivanyi, "Virtue, Piety", 99, 144-5. Another treatise that is misattributed to Birgivî and that critiques the performance of the Raghāib, Bară’at and Qadr prayers in congregation is the Risāla fì'l-Dhikr al-Jahrī (Treatise on vocal zikr). This treatise, however, has been shown by Kaylı to be the work of Ahmed Rumî el-Akhisarî instead (Kayli, "Critical Study", 72-8). 
in this regard, a variety of contemporary sources attest to the role played by his son and successor, Murad III (r.1574-95), in promoting the public celebration of the Prophet's birthday. Selânikî Mustafa Efendi (d.16oo), for instance, reports that in Rabī' al-awwal 996/February 1588, Murad III issued an imperial edict, ordering a public celebration of the Prophet's birthday throughout the empire. The sultan specifically ordered that mevlids (versified narratives about the birth of the Prophet) be recited in all mosques and masjids, that the 'sinful umma' (günâhkâr ümmet) ask for the Prophet's intercession and occupy themselves with ritual prayer and that the minarets of all mosques be illuminated with oil lamps "as on the nights of Raghāib and Barāat." ${ }^{29}$

As is evident from the wording of this order, as well as from the extant vakfyes, the custom of illuminating houses and mosques on the nights of Raghāib and Barāat in the lands of Rum actually went back considerably further and, to judge by the testimony of the Meccan scholar Jār Allāh Muhammad b. Fahd (d.1547), it had already been customary in 'the lands of Rum' in 1524 to illuminate the minarets of mosques with candles throughout the nights of Ramadan. ${ }^{30}$ It would seem, nevertheless, that mosques began to be illuminated on a more lavish scale on all the five 'holy' nights as well as on Ramadan nights in the late-sixteenth century. ${ }^{31}$ Though no one to date has established the exact chronology, it is tempting to think that the affixing of the generic name of kandil (literally oil lamp) to the nights of Mawlid, Raghāib, Mi'rāj, Barāat and Qadr in modern Turkey also has its roots in the institutionalization of these celebrations around this time.

There were a number of factors that prompted the Ottomans to invest greater significance in these nocturnal celebrations during the reign of Murad III. First, Murad had a strong interest in Sufism and cultivated close links with a number of Sufi sheikhs to fashion himself as a saintly ruler, who

29 Selânikî Mustafa, Tarih-i Selânikî, edited by Mehmet İpşirli (Istanbul: Edebiyat Fakültesi Basımevi, 1989), vol. 1, 197-8.

30 Jār Allāh Muḥammad b. Fahd, Nukhbat Bahjat al-Zamān bi-'Imārat Makka li-Mulk Ban̄̄ 'Uthmān, edited by Qays Kāzīm al-Janabī (Beirut: Dār al-Kutub al-Ilmiyya, 2010). I thank Guy Burak for this reference.

31 For a description of the illumination of mosques by a German priest who visited Istanbul in the 1570s, see Salomon Schweigger, Ein newe Reyssbeschreibung auss Teutschland nach Constantinopel und Jerusalem (Nurnberg, 1608; reprinted Graz: Akademische Druck- u. Verlagsanstalt, 1964), 192-3; for a fascinating discussion of the new trends in the illumination of mosques in a broader social and cultural context, see Kafadar, "How Dark is the History of the Night", $25^{6-7}$. 
combined in his person the highest spiritual and temporal authority. ${ }^{32} \mathrm{He}$ even seems to have entertained thoughts about being the kutb or pole, an inheritor of the spiritual legacy of Muhammad and, as such, it must have made a good deal of sense for him to promote the public celebration of Muhammad's birthday as well as other popular celebrations associated with the latter's life cycle. Second, Murad's reign was also a time of renewed warfare with the Safavids, as well as of intensified Ottoman efforts to promote Sunnism. What distinguished this phase of Ottoman Sunnitization was the increasingly active role played by sharia-abiding Sufis, who used their popular appeal not just to galvanize support for the Ottoman dynasty but also to promote a new 'Sunni-Sufi synthesis' as the heart of Ottoman religious orthodoxy.

There is evidence that some of these sharia-abiding, 'Sunnitizing' Sufi dervishes also actively encouraged Murad to endorse and promote the popular nocturnal Mawlid, Raghāib, Mi 'rāj, Barāat and Qadr celebrations as part of an imperial campaign of piety. One such Sufi was the Halveti sheikh and preacher İbrâhim b. Hakk Mehmed el-Kırımî (d.1593), also known as 'Tatar Sheikh'. In the letters he wrote to Murad in the late 158 os and early 159os, Kırımî repeatedly reminded the sultan of the blessings of various months and days in the Islamic calendar, including Mawlid and Mi'rāj, as well as Raghāìb and Barāat, and urged him to honour them by having candles and oil lamps lit throughout his realms and by ordering his Muslim subjects to occupy themselves with prayer and fasting, as well as with acts of good work, on these dates. According to Kırımî, particular vigilance was needed in this matter as they were living in bad times (yaramaz zaman), a theme that would also surface in the defence of these celebrations in the seventeenth century, as we shall see further below. ${ }^{33}$

32 On Murad's preoccupation with Sufism and its political uses, see John J. Curry, "The Meeting of the Two Sultans': Three Sufi Mystics Negotiate with the Court of Murād III", in John J. Curry and Erik S. Ohlander (eds), Sufism and Society: Arrangements of the Mystical in the Muslim World, 1200-180o (London: Routledge, 2012), 223-42; Özgen Felek, "(Re)creating Image and Identity: Dreams and Visions as a Means of Murād III's Self-Fashioning”, in Özgen Felek and Alexander D. Knysh (eds), Dreams and Visions in Islamic Societies (Albany: SUNY, 2012), 249-72.

33 The letters that Kırımî sent to Murad III remained forgotten until the mid-eighteenth century, when they were rediscovered and recopied but also misascribed to another famous Sufi of his time, Aziz Mahmud Hüdâî. For a correction of the authorship and analysis of the political contents of the letters, see Derin Terzioğlu, "Power, Patronage, and Confessionalism: Ottoman Politics as Seen through the Eyes of a Crimean Sufi, 15801593", in Marinos Sariyannis (ed.), Political Thought and Practice in the Ottoman Empire, Halcyon Days in Crete Ix: A Symposium Held in Rethymno, 9-11 January 2015 (Rethymno: Crete University Press, 2019), 149-86. For the passages on the nocturnal celebrations, see 
This reference to the corruption of the age, coming from a Sufi sheikh deeply implicated in the nitty-gritty of imperial politics, should not be taken as just a timeless topos of moral decline. This was, after all, a time when military and civic disturbances were becoming more common in Istanbul and beyond, and when mosques were emerging as spaces where crowds would gather to express discontent and even to plan collective modes of action against specific policies and their architects. ${ }^{34}$ In this connection, it made sense for the palace to reclaim the mosques as imperial spaces, and the imperialization of the already popular nocturnal prayers must have been seen as a particularly effective way to do so.

At the same time, however, the imperialization of these popular celebrations also prompted some men of religion to critique these practices in a more public fashion. An early instance of such criticism occurred during the reign of Mehmed III (1595-1603), when Sun'ullâh Efendi, shortly after being appointed şeyhülislâm in 1599, spoke out against serving candy and sherbet to the grandees (ekâbir ü a'yân) who gathered in royal mosques to listen to the recitation of the Prophet's nativity poem on the twelfth night of Rabī' al-awwal. Sun'ullâh deemed the practice an 'ugly innovation' (çirkin bid'at), as well as wasteful, and called for the money of royal endowments to be spent instead on 'feeding the poor and the righteous' in madrasas and soup kitchens. ${ }^{35}$ Clearly, however,

Mustafa Salim Güven (ed.), “Çeşitli Yönleriyle Azîz Mahmûd Hüdâyînin Mektupları”, MA thesis (Marmara Üniversitesi, 1992), 25-6, 30, 47, 74, 97, 115, 130, 146-8. From these letters we also learn that Kırımî planned to write a treatise about the mysteries associated with the months of Şaban and Ramazan (p. 30), and that he had already written a treatise about the spiritual qualities of the night of Qadr and sent it to the sultan. (130-1).

34 For examples of political grievances being expressed in royal mosques during the 159os, see Derin Terzioğlu, "Sunna-minded Sufi Preachers in Service of the Ottoman State: The Nașịhatnāme of Hasan Addressed to Murad IV", AO 27 (2010), 252-4; and Baki Tezcan, The Second Ottoman Empire: Political and Social Transformation in the Early Modern World (Cambridge: CUP, 2012), 6. For the rebellion of 1687, see 122-3. Royal mosques would play an even more critical role in the numerous political rebellions that punctuated Istanbul's history in the course of the seventeenth century.

35 Selânikî, Tarih-i Selânikî, vol. 2, 826. If Sun'ullâh expressed this opinion in the form of a fatwa, I could not locate it in his fatwa collection. However, I was able to locate another fatwa of his that deems it reprehensible (mekrûh) to serve food in masjids 'on some nights' (bazı leyâlîde). This indicates that Sun'ullâh objected to the serving of food and drinks in mosques categorically rather than to their being served to the grandees alone. For the relevant fatwa, see Sun'ullâh Efendi, Fetâvâ-yi Sunullâh Efendi, MS 502 fol.65b, Hasan Hüsnü Pasha, sk. For a slightly different reading of the Selânikî passage, see Gülru Necipoğlu, The Age of Sinan: Architectural Culture in the Ottoman Empire (Princeton: Princeton University Press, 2005), 516. 
Sun'ullâh's admonition was not heeded, and the custom of serving food and drink (including coffee) to members of the congregation on major feast days continued throughout the seventeenth century. Likewise, the celebration of the Prophet's birthday was further imperialized in the reign of Ahmed I (16o3-17), when it became a royal custom to commemorate it in the newly built mosque of Sultan Ahmed in the presence of all the high and mighty. ${ }^{36}$

When controversy truly flared up about innovations in religious worship in the 1620 os and 1630 , it was not about serving food and drink in mosques on the occasion of the Mawlid, or on other occasions, but about the congregational performance of supererogatory prayers on the nights of Raghāib, Barāat and Qadr. Indeed, all the major figures associated with the Kadızâdeli movement, such as Kadızâde Mehmed Efendi of Balıkesir, Ahmed Rumî elAkhisarî (d.1632), Üstüvânî Mehmed Efendi (d.1661) and Vanî Mehmed Efendi (d.1685), condemned the congregational performance of supererogatory prayers on these three nights as a blameworthy innovation. ${ }^{37}$ It is unclear why the Kadızâdeli preachers were so opposed to the Raghā'ib, Barāat and Qadr prayers, but said nothing about the Mi'rāj or Mawlid ceremonies. Perhaps their accommodating stance on the Mawlid ceremonies stemmed from a reluctance to go against the imperial will on this matter; or perhaps, they were simply following the traditionalist scholars of thirteenth-century Syria and Egypt in going after only those ceremonies that were being legitimated with blatantly spurious hadiths'.

Indeed, such 'spurious hadiths' were at the forefront of the objections raised to the Raghāìb and Barāat prayers by a Meccan scholar of Herati origin, 'Alī al-Qārī (d.16o5), at the turn of the sixteenth century. Like Çivizâde Muhyiddin Mehmed Efendi (d.1547), Ḥalabī and Birgivî before him, Qārī was a Hanafi scholar with a traditionalist bent, but unlike them, he was also a complete outsider to the Ottoman learned establishment, and had never held an official appointment, supporting himself instead as a calligrapher. While Qārī penned treatises in various branches of the Islamic sciences, he was particularly famous for his work on hadith criticism. It was also in a work on inauthentic hadiths that he debunked a number of traditions that were frequently cited to legitimize the Raghāib, and Bară’at prayers. ${ }^{38}$ It is worth noting that at

$3^{6} \quad$ On the imperialization of the Mawlid ceremonies, see Necipoğlu, The Age of Sinan, ${ }^{16}$.

37 For an exposition of the views of Kadızade Mehmed, Üstüvânî Mehmed and Vanî Mehmed on the matter, see Çavuşoğlu, "The Kaaḍīzādeli Movement", 248-52; for the views of Akhisarî, see Sheikh, Ottoman Puritanism and its Discontents, 131-6.

38 'Alī al-Q̄ārī, al-Asrār al-Marfǘat fì l-Akhbār al-Maw dū̄at, edited by Muhammad b. Lutfī Sabbāgh (Beirut: Dār al-Amāna, 1971), 459-62; for more on his life and thought, see 
least one of the hadiths that the Meccan scholar debunked, which attributed to the Prophet the words, "Rajab is the month of God, Sha'bān is my month and Ramadan is the month of my community", was also frequently referenced in the letters of İbrâhim-i Kırımî to Murad III. ${ }^{39}$ Could Qārī have articulated his criticism in response to the promotion of such spurious traditions by the likes of Kırımî? This is a distinct possibility, considering that there was a constant flow of scholars and Sufis as well as lay pilgrims between Istanbul and Mecca, relaying information orally as well as in writing. Considering the intellectual affinity between Qārī and the Kadızâdelis and the fact that the former's works are amply represented in the manuscript collections of Istanbul libraries, it would be worth investigating whether this Meccan scholar's objections to the said hadiths also provided an early spark for the seventeenth-century controversy about the popular nocturnal prayers.

Whatever the case may be with Qārī, there are other reasons to think that the outburst of polemic against the congregational performance of the Raghāib, Barāat and Qadr prayers in Istanbul during the 163 os was inspired, at least in part, by the objections raised to these prayers somewhat earlier in the Arab provinces of the empire. In a tract he penned to refute the legitimacy of the Raghāib, Barāaat and Qadr prayers, Kadızâde Mehmed of Balıkesir claimed to have read more than one hundred works on the topic and to have conversed about it with the "ulema of Mecca, Medina, Jerusalem, Cairo, Damascus, Aleppo, the Maghrib, [lands of the] Özbek and India", and reported on their authority that they all considered the practice inadmissible. ${ }^{40}$ Even though Kadızâde Mehmed did not indicate where he had these conversations, one of

Patrick Franke, "The Ego of the Mullah: Strategies of Self-Representation in the Works of the Meccan Scholar 'Alī al-Qārī (d.16o6)", in Ralf Elger and Yavuz Köse (eds), Many Ways of Speaking About the Self: Middle Eastern Ego-Documents in Arabic, Persian, and Turkish (14th-2oth century) (Wiesbaden: Harrassowitz Verlag, 2010), 185-200; Cağfer Karadaş, "Ali el-Kârînin Akaide Dair Eserleri ve Bazı İtikadi Görüşleri", MA thesis (Marmara Üniversitesi, 1991); idem, “Ali el-Kârî̀nin Hayatı, Selef Akîdesine Dönüş Çabası ve Eserleri”, Uludağ Üniversitesi İlahiyat Fakültesi Dergisi 5 (5) 1993, 287-99; Fikret Soyal, "Celâleddin ed-Devvânînnin Firavun’un İmânı Konusundaki Görüşleri ve Ali el-Kârînnin Eleştirisi”, MA thesis (Istanbul Üniversitesi, 2004).

39 See, for instance, Güven, "Çeşitli Yönleriyle", 47, 115, 146-8.

40 Kadızâde Mehmed, [Untitled treatise], Ms 5563, fol. 44b-47b, esp. 45b, Yazma Bağışlar, SK. The treatise is recorded under various titles such as Risâle-i Kâdızâde, Risâle-i Salât, and Risâle fî Îmân ve İslâm. For a recent discussion of this treatise, see Baki Tezcan, "A Canon of Disenchantment: Birgivi, Rumi and Kadızade", in idem, A Gift for the Turks: Studies on Islam and Its Early Modern Transformation in the Ottoman Empire. Istanbul: ISIS Press, forthcoming 2020. 
these venues was probably Cairo, a city that regularly attracted scholars from the said lands and that the Rumi preacher himself had visited at least once, in $1611 / 12 .{ }^{41}$

That Cairo was an early venue for debates on the congregational performance of supererogatory prayers is also clear from the Mebâhisüs-Salât (Discourses on Ritual Prayer), a detailed handbook on ritual ablution and prayer. The author of this work, Mustafa bin Hamza bin İbrahim bin Veliyüddin, who went by the penname of Nushî el-Nâsıhî, was originally from Bolu, but had either relocated to or frequently visited Cairo. He was also living in that city in $1624 / 5$, when a debate erupted in that town about the legitimacy of the congregational performance of supererogatory prayers. ${ }^{42}$ It might be worth pointing out that although Nushî dates this debate to $1624 / 5$, the text in which he presents his views on the topic was the product of a later period. Nushî writes that he compiled the material for his handbook over the course of some two decades, finished the task of compilation and translation in 1633/4, and made a clean copy of the work in $1635 / 6 .^{43}$ Since the author was still in Cairo in $1635 / 6$, it might seem that he was basically responding to the debate in that specific city rather than the one raging in the principal cities of Rum. ${ }^{44}$ That he chose to bring up this issue only in his Turkish-language compendium on ritual prayer and not in the Arabic version, however, suggests that the intended audience of his remarks on the congregational performance of supererogatory prayers was first and foremost the Turcophone Muslims of Rum. This does not of course preclude the fact that the Rumis who participated in this debate were scattered across the Ottoman territories, and that some lived, like Nushî, in smaller Rumi communities surrounded by non-Rumis in such cosmopolitan centres as Cairo.

41 For Kadızâde Mehmed's time in Cairo, and his contact with Arab scholars, there, see Baki Tezcan, "The Portrait of the Preacher as a Young Man: Two Autobiographical Letters by Kadizade Mehmed from the Early Seventeenth Century", in Marinos Sariyannis (ed.) Political Thought and Practice in the Ottoman Empire, Halcyon Days in Crete IX: A Symposium Held in Rethymno, 9-11 January 2015 (Rethymno: Crete University Press, 2019), 202-3.

42 Nushî, Mebâhisü’s-Salât, Ms 948, fol. 151b-155a, 181a-187b. For a preliminary discussion of Nushî’s identity, see Derin Terzioğlu, "Where İlm-i Hạal Meets Catechism: Islamic Manuals of Religious Instruction in the Ottoman Empire in the Age of Confessionalization", $P P 220$ (2013), 88. For the identification of his full name, see Tezcan, "The Portrait", 228-9.

43 Nushî, Mebâhisü’s-Salât, Ms 948, fol. 2b-3a, 111a.

44 For his whereabouts in that year, see Nushî, al-Hayāt Sharh, 136b-137a. 


\section{In Defence of the Congregational Performance of Supererogatory Prayers}

For the rest of this chapter, I will dwell mainly on the arguments made by Nushî and another early seventeenth-century scholar, 'Abdülkerim Sivâsî, in defence of the congregational performance of supererogatory prayers on the nights of Raghāib, Barāat and Qadr, as they offer interesting perspectives on the question of religious custom and change. Before turning to these arguments, however, it might be helpful to first locate these scholars a bit more precisely in the social and religious landscape of the early-seventeenth-century Ottoman Empire.

Who, or what kind of a Muslim was Nushî, and what was his relationship to the Kadızâdelis, if any? Since the author does not appear in any of the principal biographical dictionaries of the time, we can answer this question only in the light of his own writings. Nushî describes himself as belonging to 'the lowest ranks of the ulema' (ednâ-i zümre-i 'ulemâ), but he also writes of being the only person in his time to hold a certificate of transmission (sened) handed down across twenty-three generations from the founding father of the Hanafi legal school, Abū Ḥanīfa (d. 767$)^{45}$ Even although Nushî does not provide any further information about his occupation, his use of the honorific 'Sheikh' and his penname 'Nushî', meaning 'advice-giver', suggest that he made his living as a preacher. ${ }^{46}$ Such an occupation would also be consonant with the kinds of works he penned. Of the six works that we can attribute to Nushî, two are in Turkish, and the rest in Arabic, but all are basically handbooks written with the aim of enlightening ordinary men and women about the fundamentals of Islamic faith and practice. ${ }^{47}$ In these works, Nushî pres-

\section{Nushî, Mebâhisü’s-Salât, 1a.}

46 Ibid., 237b.

47 One of these works is a Turkish 'ilmihâl titled Mebâhisü'l-Îmân or Mebhas-ı Îmân, which was written sometime between 1633 and 1636, and is discussed in Terzioğlu, "Where i்lm-i Hāal Meets Catechism", 89-107. The other Turkish work is Mebâhisüs-Salât, discussed above. The remaining texts are in Arabic, and comprise al-Hayāt Sharh Shurūt al-Salāt, and Manqülat al-Dalāill, both which also deal with issues of ritual ablution and prayer, Sharh Wașiyyat al-Imām al-Azam, which is a commentary on the famous creed attributed to Abū Ḥanīfa, and which was written in 1638/9, al-Risālat al-Umniya l-Muhimma fı́ Bayāni'l-Udhiya 'alā l-Umma, which deals with ritual animal sacrifice, and which was written in 1638 , and Risāla fì Dhikri A'immati l-Arba'a l-Mujtahidīn wa-Ba'adil'-Masāili l-Fighiyya, which deals with the founding fathers of the four Sunni legal schools and some legal issues. For a discussion of the authorship of these last five works, see Mustafa 
ents himself as basically a 'compiler' (câmi', musannif) of religious knowledge, someone who culled, translated and reorganized key passages from 'reputable books' (kütüb-imu'tebere) for the benefit of laymen and women. In contrast to Kadızâde Mehmed, who often used the works of others without acknowledgment, Nushî was extremely careful to identify his sources and included in each of his compendia a separate list of 'reputable books'. As one might expect from a Rumi scholar, most of his sources were by Hanafi-Maturidi scholars, and in his Turkish 'ilmihâl, he directed his readers to consult, in addition to the many Arabic creeds and legal compendia, the Turkish ilmihâls of Birgivî Mehmed and Ahmed Rumî el-Akhisarî.

There is evidence that at least one work of Nushîs, the above-mentioned Turkish ilmihâl, was popular in Kadızâdeli circles, so much so that in quite a few codices the text is misattributed to Kadızâde Mehmed and in some other codices, selections from it are reconfigured in the form of an independent treatise attributed to the latter. ${ }^{48}$ The mix-up between the two men is actually quite understandable in the light of their many similarities: both men greatly valued the writings of Birgivî Mehmed; both were strongly Sunna-minded and objected to such popular pastimes as smoking and frequenting coffeehouses as well as the Sufi practices of ritual music and dance and the melodic chanting of the names of God as 'blameworthy innovations'; and yet, both were at the same time Sufis themselves, and even adherents of the same, Nakşbendi, tarikat, which stood out among the various Sufi tarikats for the sobriety of its rituals and the especially high regard of its adherents for the sharia. ${ }^{49}$

As we shall see below, Nushî and Kadızâde Mehmed did not think alike on all issues: they actually took the opposite sides in the debate on the congregational performance of supererogatory prayers. There is even reason to believe that Nushî deferred on that issue to someone who may have been affiliated

İsmail Dönmez, “Kuşadahı Mustafa bin Hamza ve 'Netâicül-Efkâr fi Şerhi'l-İzhâr' Adlı Eseri (İnceleme ve Tahkik)", Ph.D. dissertation, Marmara Üniversitesi, 2013, 27-30.

48 For example, see Nushî el-Nâsshi/Mustafa b. Hamza b. İbrahim b. Veliyüddin, Mebhas-ı Îmân MS 5563, fol. 59a-137a, Yazma Bağışlar, sk. For an early example of the short risâle version of the same text, see Kadızâde Mehmed, MS TY 3529, fol. 116b-121a, TY, IUK. We can confidently rule out the authorship of Mebhas-ı Îmân by Kadızâde Mehmed, as the said work is explicitly referenced in Mebâhisüs-Salât (10a), and as the author clearly identifies himself by name in the latter work.

49 While Nushî's Sufi identity comes out the most clearly in his 'ilmihâl, he is identified as a Nakşbendi in the manuscript copies of several other works. For one such copy of his Mebâhisü's-Salât in Cairo, see Fihris Makhtūtāt al-Turkiya al-'Uthmāniyya, vol. 4, 19, no. 4192. For Kadızâde Mehmed's Nakşbendi affiliation, see Tezcan, "The Portrait of the Preacher", 202. 
with the Kadizâdelis' arch-enemies. Nushî writes that when he first heard of the objections to the congregational performance of supererogatory prayers, he wanted the opinion of a master jurist on the issue. Thus, he turned to 'Abdülkerim Sivâsî, whom he describes as a "verifying scholar, a meticulous man of religion, a perfected man of virtue, a practising ascetic, and a second Abū Yūsuf". As far as I could ascertain, the only 'Abdülkerim Sivâsî who lived in this time period and who could fit the profile given by Nushî was a younger brother of the famous Halveti sheikh 'Abdülmecid Sivâsî (d.1639), who was the foremost adversary of Kadızâde Mehmed of Balıkesir. In the vita of Şemseddin Sivâsî, written by Receb Sivâsî sometime during the reign of Ahmed I (16o3-17), Abdülkerim Sivâsî is mentioned as working as a preacher in a Friday mosque in Zile in north-central Anatolia. ${ }^{50}$ Unfortunately, I have been unable to find any trace of this 'Abdülkerim in later years, so if he were the same person as the scholar who issued the fatwa in answer to Nushî's question, it is impossible to tell whether he, too, was in Cairo at the time, or whether Nushî sought him out by writing him a letter. Neither do we know whether 'Abdülkerim Sivâsî was also affiliated to the Sivâsî branch of the Halveti tarikat, but even if he had been, this need not have prevented Nushî from honouring him, for, as Dina Le Gall has pointed out, there was no categorical animosity between adherents of these two brotherhoods at the time. ${ }^{51}$ It would thus not have been strange for Nushî and 'Abdülkerim Sivâsî to think similarly on various issues.

50 Receb Sivâsî, Necmü'l-Hüdâ fi Menâkıbi’̧-Şeyh Şemseddîn Ebi’s-Senâ, Ms 694/2, fol. 40a, Lala İsmail, sk. It has been published as Hidâyet Yıldızı: Şems-ed-dîn-i Sivâsî Hazretlerinin Menkıbeleri, translated by Hüseyin Şemsi Güneren and edited by Fatih Güneren (Istanbul: n.d.), 73. Astonishingly, this rich source on the Halveti-Sivâsî sheikhs has been remarkably underutilized by modern scholars. This is a serious shortcoming in that some of the basic information contained in this work contradicts the information given by the later biographers, and which is often repeated uncritically in the secondary literature. For instance, we learn from this text that Receb Sivâsî did not die in 1599 or 16oo, as was claimed by the later biographers, but was still alive during the reign of Ahmed I (16o3-17), when, he says, finished his vita of Şemseddin Efendi. We also learn that 'Abdülmecid Sivâsî himself was still based in Zile at the time Receb Sivâsî was writing his vita. Clearly, it would be important to verify all these dates against archival evidence, a task that lies outside the scope of this chapter. For the standard biographical narrative on 'Abdülmecid Sivâsî, based overwhelmingly on the later biographical sources, see Cengiz Gündoğdu, Bir Türk Mutasavvıfı Abdülmecîd Sivâsî (971/1563-1049/1639): Hayatı, Eserleri ve Tasavvufi Görüşleri (Ankara: Kültür Bakanlığı, 200o), 39-85, 134-47; idem, "Sivâsî, Abdülmecid", DIA 37 (Istanbul, 2009), 286-7.

51 Dina Le Gall, "Kadızadelis, Nakşbendis, and Intra-Sufi Diatribe in Seventeenth-Century Istanbul", The Turkish Studies Association Journal 28 (1-2) 2004, 1-28; idem, A Culture of Sufism: Naqshbandīs in the Ottoman World, 1450-1700 (Albany, NY: SUNY Press, 2005), 
This having been said, the arguments that Nushî and 'Abdülkerim Sivâsî presented in defence of the congregational performance of supererogatory prayers were complementary, but not identical. More as a compiler of juridical opinions than as a master jurist, Nushî launches the discussion of the Raghāib, Barāat and Qadr prayers by restating the conventional Sunni-Hanafi view that "it is better to perform supererogatory prayers at home and then go to the mosque." However, right after, he qualifies this remark with the words "but it has been said that in our time it is better to perform supererogatory prayers in mosques and masjids than at home" (my emphasis). ${ }^{52}$ Perhaps because it was no light matter to argue that shar'i judgments could change over time, Nushî himself does not elaborate on this line of argument, but defers instead to the expert opinion of 'Abdülkerim Sivâsî on this matter.

The fatwa issued by Sivâsî, and reproduced, seemingly in full, in the Mebâhisüs-Salât, begins by unequivocally stating that "it is not permissible to prohibit the (congregational performance of the supererogatory) prayers of Raghāib and Qadr."53 Even so, however, Sivâsî acknowledges that the said prayers are an instance of 'innovations in religious worship'. He also concedes that the earliest Muslim authorities strongly disapproved of such innovations. He, then, gives the example of Ibn 'Abbās, a cousin of the Prophet Muhammad and an important early transmitter of hadiths. Accordingly, when Ibn 'Abbās saw some Muslims form a circle and perform zikr in the mosque of the Messenger of God, he beat them with a stick and expelled them from the mosque, because they were indulging in a liturgical act that was not based on the example of the Prophet. Clearly, Sivâsî considered the precedent set by Ibn 'Abbās to constitute the basis of all the later indictments of such innovations as the Raghāib, Barāat and Qadr prayers, and in the rest of his answer, he strives to show why this judgment of Ibn 'Abbās can no longer apply 'in our time'.

Sivâsî builds his counterargument by citing the juridical principle that 'shar ' $i$ judgments change with the change of times'. He also illustrates why it would not serve the interests of religion to apply the prohibition of Ibn 'Abbās to the case of the Raghäib and Qadr prayers in his own time. The gist of his argument is that the Muslims of his time are not only less pious and righteous

chapter 6. For a prominent Nakşbendi who polemicized against the Kadizâdelis, see Barbara Rosenow von Schlegell, "Sufism in the Ottoman Arab World: Shaykh 'Abd al-Ghanī al-Nābulusī (d.1143/1731)", Ph.D. dissertation (University of California, Berkeley, 1997).

52 Nushî, Mebâhisü’s-Salât, 149b-15oa.

53 Ibid., 153a-154b. For the modern Turkish transliteration and English translation of the text, see Appendix. 
than the first three generations of Muslims, but are also exposed to many more worldly temptations from wine-houses to coffeehouses and even to brothels. In such a context, the only remedy can be to encourage people to go to mosques and masjids, even if the acts of worship they perform in these places are not entirely free of abomination (kerâhet). It is interesting that Sivâsî also mentions the illumination of mosques and masjids with candles and oil lamps among the practices that would have been foreign to the austere piety of the earliest Muslims. In this manner, he reminds his opponents that they would have to object to many more features of devotional life, if they were to be logically consistent and insist on absolute adherence to the example of the Prophet and the earliest Muslims. He also drives home the same point by asking a hypothetical opponent: "O ignorant one, is there any worship in our own time that is free of abomination?" In Sivâsî's esteem, to insist on a rigid and narrow application of the Sunna at this point in time was not only infeasible but was also bound to be counterproductive, depriving Muslims of valuable channels to orient themselves towards God.

Reading Sivâsîs argument, one is immediately reminded of Baber Johansen's argument about the complex relationship between the religio-moral and legal dimensions of the shariah. Indeed, one could say that Sivâsî̀s fatwa represents an excellent example of how a premodern mufti could negotiate the productive tension between religio-moral and legal norms. There is no doubt that Sivâsîs argument foregrounded what he considered to be the higher dictate of 'religiosity' over strict adherence to an earlier legal ruling. Without denying the moral authority of the first generations of Muslims, who had formulated the legal ruling against performing supererogatory prayers in congregation, Sivâsî highlighted the impossibility of replicating their ways in the changed circumstances of his own times. Rather than trying to adhere blindly to the letter of the pronouncements of the selef, who lived in a significantly different context, he argued, it is important to figure out how to realize the essence of their call and live a life of piety and godliness in these more complex and challenging times.

It is clear from his presentation of the fatwa that Nushî agreed with Sivâsî on this matter. Interestingly, however, in the rest of the text, Nushî defends the congregational performance of supererogatory prayers on more technical grounds and with reference to its being rooted in local customs. The early authorities that ruled against the practice, Nushî argues, were actually targeting only those cases in which a special call to prayer preceded the congregational performance of supererogatory prayers. However, since no such special call to prayer precedes the congregational performance of supererogatory 
prayers in the lands of Rum, the earlier condemnations cannot apply to their case, he reasons. ${ }^{54}$

Nushî also takes care to stress that the Muslims of Rum who have long been performing their supererogatory prayers in congregation have done so with the backing of a substantial corpus of texts. Not surprisingly, most of what he cites in this connection are juridical works by Hanafi scholars, including both such well-established texts of the Transoxanian tradition as the Ziyādāt of Muḥammad al-Shaybānī (d.805), al-Yawāqüt fìl-Mawāqüt of Najm al-Dīn al-Nasafĩ (d.1142), Tajnīs Majmū' al-Nawāzil of Ahmmad b. Mūsā al-Kashshī (d.after 1155), al-Muhịt of Burhān al-Dīn Maḥmūd al-Bukhārī (d.1174) and more recent works of the Mamluk and Ottoman lands such as an unspecified work by the Mamluk scholar of Ayntabi origin, Abū Muḥammad b. Maḥmūd Badr al-Dīn al-'Aynī(d.1451), Commentary on the Nuqāya by Abdülvâcid Muhammed el-Meşhedî el-Kütahyavî (d.1434), the Dürer and Gurer by Molla Hüsrev (d.148o) and the Fetâvâ of Ebüssuûd. The Shafi'i tradition is represented with a lone work, al-Fatāwā al-'Abbādī by Abū 'Āṣim Muḥammad al-'Abbādī (d.1066).

In addition, Nushî also cites three works that are not so much juridical works as works on devotional piety from a Sufi perspective, namely, Abū Hâmid al-Gazzālī’s (d.1111) Ihyā 'Ulūm al-Dìn, Abū Ṭālib al-Makkī's (d.996) Qūtal-Qulūb and Faḍlallāh b. Muhammad b. Ayyūb’s (d.1267/8) Fatāwā al-Sūufyyaa. ${ }^{55}$ The use of such Sufi or Sufi-inspired religious handbooks to justify contested religious practices was actually both common and bitterly contested in this period, with learned Sufis and Sufi-inclined scholars citing them as sources of authority and strictly legalist, traditionalist scholars contesting their use. ${ }^{56}$

The third and last category of works that Nushî cites consists of the canonical hadith collections of Muhammad b. Ismāīil Bukhārī (d.870), Muslim b. Ḥajjāj (d.875) as well as Jāmic al-Ușül li-Ahạadith al-Rasūl of Ibn al-Athīr (d.1210), which is a collation of the hadiths found in the six canonical hadith collections. He also cites a hadith (not found in any one of these six canonical

54 Ibid., 151b-153a, 181a-b.

55 Ibid., 154b-155a, 181a-186b.

56 For the biography of the author of al-Fatāwā al-Ṣūfiyya, see Faḍlallāh b. Muhammad b.

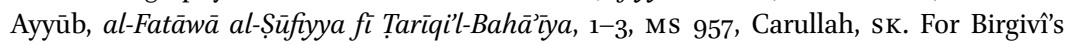
objections to al-Fatāwā al-Ṣüfiyya, see Birgivî Mehmed, Rasāill al-Birkawī, edited by Aḥmad Hādī al-Qașșār (Beirut: Dār al-Kutub al-'Ilmīya, 2011), 79-8o. I thank Yavuz Aykan and Şükrü Özen for these references. For similar objections by Aydınî, see fn.63. For Vanî’s

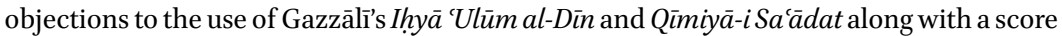
of other 'books of the Sufi sheikhs' (kütüb-i meşâyih-i tarîkat) as jurisprudential sources (kütüb-i fikh-ı şerîf ve şer'i latîf), see Vanî Mehmed, Muhyîss-Sünnet Mü’mitül'-Bid'at, fol. 2a, ms 663, Kasidecizade, sk. 
compilations) - "What the Muslims see as praiseworthy is also praiseworthy in the eyes of God." (Li-en mâ re'ehu'l-muslimûne hasenen fe-hüve 'ind'Allâhi hasenun. $)^{57}$

Nushî actually cites this last hadith not once but twice, as it is central to his argument that jurists must make an allowance for customs that are widespread among the Muslims when they are not expressly against the principles of Islamic law. It is for this reason that the author emphasizes that supererogatory prayers have long been performed in congregation "in Anatolia and its villages, in Constantinople and the surrounding areas, in Edrene (modern Edirne) and the villages of Rumelia, ... and in the lands of the Tatars ... and in Bukhara, Samarkand and India." 58 Thus, the author points to a vast geographical expanse in which the congregational performance of supererogatory prayers was a deeply ingrained custom, comprising not just the lands of the Ottomans but many of the eastern lands of Islamdom, where Hanafism was the dominant legal school.

However, it is in defence of the Ottoman/Rumi practice of Islam that the author turns out to be the most emphatic. Indeed, not content merely to defend the congregational performance of supererogatory prayers by Ottoman Muslims, Nushî goes fully on the offensive, and imputes politically subversive motives to those who condemn these practices as a 'grievous error' (dalâlet). He writes:

In particular, the rulers of the House of Osman, who are sultans of the Arabs and the Acem and servants of the two holy sanctuaries (may God extend their lives till the end of times), together with their mothers and fathers and glorious ancestors, have long performed these prayers. Hence the (true) intent of those who say that it is a grievous error (dalâlet) to perform these prayers is to call the sultan of the House of Osman and his sons people of error. May God preserve us from such an error! May the Lord (praise be to Him and Exalted be He!) preserve the sultans of the House of Osman from error! Amen! And another intent of those who call the people who perform these prayers people of error is to slander and attack the viziers of the House of Osman, the ulema of the House of Osman and the sheikhs of the House of Osman as people of error. ${ }^{59}$

\footnotetext{
57 Nushî, Mebâhisü’s-Salât, 186b. For this hadith, see Ahmad b. Ḥanbal, Musnad, vol. 1, 379; Ṭabarānī, Mūjam al-Awșaț, vol. 4, 58; and Ḥākim, Mustadrak, vol. 3, 83.

$5^{8}$ Nushî, Mebâhisü's-Salât, 186b-187a.

59 Ibid., $187 \mathrm{a}-\mathrm{b}$.
} 
What Nushî argues here is essentially that the congregational performance of superegotary prayers has the backing of Ottoman royal authority. Remarkably, however, he evokes the authority of 'the House of Osman' not just with reference to the Ottoman dynasty, but also with reference to the greater state edifice, extending from the sultans and the female and male members of the royal family to the viziers, the ulema and all the way down to the sheikhs. As such, this passage stands out as a rather early articulation of a more extended and corporate as well more bureaucratic notion of the state in the Ottoman lands. ${ }^{60}$ The inclusion of the meşâyih in this state edifice is particularly significant, and is in line with the increased visibility of the sheikhs in the political imaginations of seventeenth-century Ottomans, and further illustrates the self-identification of at least some members of the meşâyih with the Ottoman state. This is a point of no little relevance to the wider debates about who could legitimately claim to be arbiters of orthodoxy/praxy in the Ottoman lands. It appears from this passage that Nushî not only considered the norm-setting functions of Ottoman royal authority to be self-evident and widely accepted, but also derived a degree of juridical authority from it himself via being a small $\operatorname{cog}$ in the state edifice.

It is worth noting, however, that even as Nushî was attacking opponents of the congregational performance of supererogatory prayers as enemies of the Ottoman social, political and moral order, criticism of the popular nocturnal prayers (and other controversial 'ancient customs') was no longer confined to non-Ottoman, non-Rumi and non-Hanafi Muslims, but was also spreading among the 'ulema and sheikhs of the House of Osman'. It might be appropriate, then, to end this section with a brief consideration of the counterarguments made by one such Rumi Hanafi critic, Mehmed b. Hamza el-Aydınî (d.after 1706). Aydınî was a provincial scholar, who wrote most of his works in the last decade of the seventeenth and the first decade of the eighteenth century, and who was regarded by some of his contemporaries as a 'second Birgivi'. This epithet was not without reason, as Aydınî was opposed to many of the same 'innovations' as Birgivî and the Kadızâdelis, and he articulated his opinions about them in more than sixty treatises. In one of these treatises, entitled Risâle fî

6o On the emergence of a more bureaucratic and impersonal concept of the state in Ottoman political thought between the sixteenth and eighteenth centuries, see Marinos Sariyannis, "Ruler and state, state and society in Ottoman political thought", Turkish Historical Review 4 (2013), 83-117. For explorations of the social and political dynamics behind this conceptual change, see Rifa'at 'Ali Abou-El-Haj, Formation of the Modern State: The Ottoman Empire, Sixteenth to Eighteenth Centuries (New York: sunY Press, 1991); Tezcan, The Second Ottoman Empire, passim. 
Beyâni Kerâhatit-Tahrîmiyye ve't-Tenzihiyye (Treatise on the clarification of permissible and impermissible abomination), he also touched on the debate on the congregational performance of supererogatory prayers. ${ }^{61}$

It is not certain, but quite probable that Aydınî wrote this treatise in rebuttal of the arguments presented in the Mebâhisü’s-Salât. Though Aydınînever mentions Nushî or Sivâsî by name, he writes in scathing terms of "certain authors of deficient knowledge in our times [who] compile books by assembling bits and pieces from a variety of other books as if they are collecting wood at night". He critiques these writers for misquoting and misinterpreting their sources. He also objects to the interpretation of Quranic verses and hadiths by these writers on the grounds that the latter are basically mukallid scholars and are qualified only to 'imitate' the opinions of the master jurists of the past. He criticizes, among others things, how these writers have interpreted the hadith. "What the Muslims see as praiseworthy is also praiseworthy in the eyes of God." He argues that 'the Muslims' (el-Müslimûn) in this hadith are not Muslims in general but the selef, and cannot at any rate include the 'people of bid'at'. Hence, he concludes, the hadith cannot be used to justify such popular but abominable practices as the congregational performance of supererogatory prayers, as the author of the Fatāwā al-Şüfiyya (and following him, Nushî) had done. As if in direct response to Nushî's evocation of Rumi/Ottoman customs, Aydınî also retorts that even if many 'virtuous' people of Rum continue to perform supererogatory prayers in congregation, many other 'virtuous' people in the Hijaz, Sham, Egypt, Maghreb, Yemen, Samarkand, Bukhara, Hind and Sind have been giving them up. How, then, can one rule that the Muslims of Rum are more 'virtuous' than the rest? In such instances of disagreement, what needs to be done is to decide in accordance with the Book and the Sunna, and when and where there is doubt, it is necessary to err on the side of caution and prohibit any practice that is suspected of being an abomination. ${ }^{62}$

Even though Aydınîs arguments summarized above may seem primarily to target the arguments of Nushî, aspects of his arguments can be seen as an indirect response to Sivâsî's more historically and rationally grounded arguments as well. Aydınî makes it clear that he considers 'abominations' in ritual worship ('ibâdet) to be far worse than 'abominations' in human relations (mu'âmelât), and he explicitly criticizes those who advocate lenience towards the former. Although Sivasi in the fatwa discussed above did not argue that 'abominations'

\footnotetext{
61 On Aydınî and his works, the most comprehensive work is that of Recep Cici, Bir Osmanlı Fakihi: Âlim Muhammed b. Hamza'nın Fıkıh Risâleleri (Bursa: Emin Yayınları, [2006?]).

62

This discussion is based on the detailed summary given in ibid., 39-46.
} 
in ritual worship should be tolerated as a matter of principle, he had, after all, argued that in a world teeming with sinful temptations, religious practices involving some degree of 'abomination' represented the lesser of two evils and had to be allowed.

Significantly, however, the more central aspect of Sivâsîs argument was that the rejection of the performance of supererogatory prayers in congregation by the Prophet's cousin Ibn 'Abbās was no longer applicable in later times, and Aydınî seemingly has nothing to say about that. It is worth dwelling a bit more on this silence, as Aydınî himself was no stranger to the legal maxim about the mutability of legal assessments over time. Quite to the contrary, in another treatise, he himself brings up the same principle, explaining that legal judgments of earlier authorities have to be revised when the underlying reasons ('illet) change. One of the examples he discusses in this context is the shift in juridical opinion concerning the attendance of women in mosques. Whereas the Prophet had explicitly forbidden fellow Muslims from banishing women from mosques, Aydınî argues, later authorities had found it necessary to change his ruling and to banish first younger and then, also older women from mosques, seeing that each successive generation had become more corrupted than the previous and considering that the presence of women posed a graver moral danger to the (male) congregations in these corrupted times. ${ }^{63}$

It is worth stressing that both Aydınî and Sivâsî shared the Sunni Muslim belief in the moral corruption of Muslims over time, but whereas Sivâsî advocated fighting this corruption by introducing new elements into the repertoire of Muslim piety from the realm of popular practice, Aydıni thought that the corruption would be best fought by the introduction of ever stricter strictures, intended to keep people (in this case, women, construed to be morally and socially inferior) in check. Ultimately, it seems, it was the individual scholars' social and political priorities and commitments that determined how they interpreted the religio-legal tradition and how they applied its insights to their own surroundings and times.

\section{3}

\section{Conclusion}

This chapter has been an attempt to tackle the question of the mutability of shari judgments through the debate about the permissibility of the

63 For an annotated Arabic edition, English translation and analytical discussion of this treatise, see Cici, Bir Osmanlı Fakihi, 33; see also Reinhart, "When Women Went", 116-28. 
congregational performance of supererogatory prayers. I have tried to show that the debate about the congregational performance of supererogatory prayers actually touched on many of the central questions that Ottoman scholars (and some laymen) debated in the course of the sixteenth and especially, seventeenth centuries: are all innovations in worship categorically bad, or can some be deemed useful and therefore permissible? Is it permissible to root out 'innovations' that have become part of 'local custom'? Do the religio-legal pronouncements of the Prophet, the Companions and the Successors always bind later generations of Muslims, or can they be revised on the grounds of the juridical principle that 'shar'i judgments change with the change of times'?

We have seen above that the Ottoman scholars who defended the congregational performance of supererogatory prayers in general and the Raghāib, Barāat and Qadr prayers in particular often did so on the grounds that these prayers were deeply rooted in 'local custom'. This was the position of various scholars from Şeyhülislâm Ebüssuûd in the mid-sixteenth century to Sheikh Nushî and Kâtib Çelebi in the early and mid-seventeenth century respectively. Yet, this position did not directly address the problem of the traditionalist objections that were directed at the practice in the first place. This was precisely what 'Abdülkerim Sivâsî attempted in the fatwa cited by Nushî. Evoking the juridical principle 'shar'i judgments change with the change of times', Sivasî argued that the strict prohibition by the Companions and Followers of even the smallest innovation in matters of worship could not be held to apply automatically to the rather different conditions of their own times. In a world that was infinitely more complex and that teemed with so many more opportunities for sin, innovations that attracted people to a life of piety could no longer be prohibited. This was a powerful line of argument that contained in itself the possibility of a more radical critique of Sunni traditionalism. It was also an argument that could be deployed, at least in theory, to defend not only the congregational performance of supererogatory prayers but also a whole set of other popular religious practices from the melodic recitation of the Quran to the Sufi rituals of vocal zikr, semâ $\hat{a}^{\complement}$ and devrân. ${ }^{64}$

Strangely, this line of argument does not seem to have been widely utilized by the Rumi scholars. It is true that the gentlemen whose conversations with

64 This is not to say that all critics of the Kadızâdelis wanted to defend all these practices. As we have seen, Nushî, for one, opposed the semấ ceremonies as bid'at. Whether or not Sivâsî agreed with him on this particular matter, what is important is that Sivâsî's argument against traditionalist objections to the congregational performance of supererogatory prayers could be extended also to other items of debate. 
the Kadizâdelis were cited at the beginning of this chapter poked fun at the unreasonableness (as they saw it) of the Kadızâdeli demands that they live like Muslims in the day of the Prophet. However, theirs was hardly a jurisprudential argument, and was probably made half in jest. The closest analogue that I could find to Sivâsîs historically- and rationally-grounded critique of Sunni traditionalism in the wider Ottoman literature is Kâtib Çelebi's Mîzânül-Hakk fi Ihtiyâri'-Ehakk (Balance of Truth for Choosing the Most True), and this tellingly is also the work of a non-specialist. Kâtib Çelebi, after all, was neither a jurist nor even a member of the ulema proper, but was rather a largely selftaught bureaucrat, who had, on his own initiative, attended the circles of some madrasa professors, and who wrote his work in Turkish for the benefit of laymen as much as scholars.

In the prologue to this work, Kâtib Çelebi makes an extensive case for the use of reason and the rational sciences and highlights their importance for the correct interpretation and application of religio-legal principles. Always keen to take into consideration both sides of an issue, he also acknowledges that the Companions of the Prophet had initially opposed the study of the rational sciences and the Greek books because they were worried about the infiltration of non-Islamic ideas into their newly adopted Islamic faith. However, after the Muslims had codified all the principal Islamic sciences, they had felt safe enough to study the rational sciences and lifted the ban on them in the time of the Umayyads and Abbasids. Hence, Kâtib Çelebi argues, it behoves the intelligent Muslims of the present times to follow the examples of these scholars and not reject the use of reason. ${ }^{65} \mathrm{He}$ also illustrates with some concrete examples how a mufti with insufficient grounding in the rational sciences is likely to err when deliberating on shar $i$ matters.

The rest of Kâtib Çelebi's book can be read as an illustration of the methodology he advocates in the preface. In chapter after chapter, he presents what he considered the most reasonable and balanced line on the principal issues of religio-legal controversy in his own time, using both proofs from the Quran, hadiths and various authoritative juridical sources, and rational argumentation. In chapters devoted to some of the primary participants in these debates, Kâtib Çelebi also critiques Birgivî and Kadızâde Mehmed for being insufficiently grounded in rational thought. According to Kâtib Çelebi, Birgivî had

65 Katib Çelebi, Balance of Truth, 21-32, esp. 24-5. For an analysis of Kâtib Çelebi's views on this matter, also see Seyfi Kenan, "Doğruyu Dengede Tutmak: Mîzânül-Hak Çerçevesinde Kâtip Çelebi 'nin Bilgi ve Eğitim Anlayışı”. In Said Öztürk (ed.) Vefatının 350. Yılında Kâtip Çelebi (Istanbul: İstanbul Büyükşehir Belediyesi, 2007), 87-91. 
been proficient in logic but not in the other rational sciences, and he had been especially ignorant of history, which, if he had studied it, would have taught him the importance of 'local custom'. Kâtib Çelebi was even more dismissive of Kadızâde Mehmed in this matter, deeming the latter's knowledge of the rational sciences to be quite 'rudimentary and superficial'.66

It would be inaccurate, however, to say that the seventeenth-century Ottoman debate on bid'at was essentially a replay of the old conflict between 'rationalists' and 'traditionalists'. In his recent forays into the study of logic and kelâm in the seventeenth-century Ottoman Empire, Khaled El-Rouayheb has cast doubt on the once widely-accepted view that the rise of the Kadizâdelis was accompanied by a decline of interest in the rational sciences. ${ }^{67}$ As far as the jurisprudential literature is concerned, too, the picture seems to have been a good deal more complex. Just as Sunni traditionalism was not only the monopoly of the Kadızâdelis but was also embraced by many Sufis, ${ }^{68}$ neither was systematic legal reasoning the monopoly of the anti-Kadızâdelis. Among the Kadızâdelis (and like-minded scholars) Ahmed Rumî el-Akhisarî comes to mind as a strongly traditionalist scholar, who also boldly defended the ability of the scholars of his time to practise ijtihad. ${ }^{69}$ Another scholar who combined strict adherence to the Sunna with systematic legal reasoning was Mehmed b. Hamza el-Aydınî, whose arguments against the congregational performance of supererogatory prayers as well as against the attendance of women in mosques have been discussed above. Interestingly, like Sivâsî, Aydınî also acknowledged the principle that legal judgments change with the change of time, but allowed such reassessments only if they were more stringent than previous ones, helping to keep in check those forces that he considered posed a threat to the moral integrity of the Islamic community.

Ultimately, what distinguished Aydınî from Sivâsî was less their positions on rational argumentation and more their approaches to the religio-moral dimensions of the sharia. Whereas Sivâsî saw no harm in relaxing legal judgments and admitting religious innovations into the practices of Muslims if he thought they served the purpose of reorienting people towards God and piety, Aydınî was far less tolerant of practices about which there was the slightest doubt

66 Katib Çelebi, Balance of Truth, 130, 136-7.

67 Khaled el-Rouayheb, Islamic Intellectual History in the Seventeenth Century: Scholarly Currents in the Ottoman Empire and the Maghrib (Cambridge: CUP, 2015), 13-59.

68 Derin Terzioğlu, "Sunna-minded Sufi Preachers", passim.

69 For Akhisarî's views on ïtihād, see Ahmed el-Akhisarî, Against Smoking: An Ottoman Manifesto, edited and translated by Yahya Michot (Leicestershire: Kube Publishing: 2010), $67-70$. 
of illegitimacy; and he would allow legal reassessments only if they reduced rather than expanded the scope of religious, moral and legal ambiguity. For him, as for many modern Muslims, adhering as strictly as possible to the law was at all times the best way to safeguard religion and morality.

To the extent that it is possible to generalize from this specific debate to the larger seventeenth-century Ottoman debates about the Sunna, one could perhaps say the following: Although the Kadızâdelis (and like-minded scholars) were not quite the forerunners of the Wahhabis they have been made out to be, they did share with the traditionalist, Sunni revivalist movements of the lateeighteenth and nineteenth centuries a decreasing 'tolerance for ambiguity', as well as a narrower understanding of the sharia as Islamic legal normativity. ${ }^{70}$

While it exceeds the scope of this chapter to probe the reasons for this epistemic shift, if one may call it that, suffice it to note that the Kadızâdelis themselves drew on the scholarship of a small but distinguished group of hadith scholars and jurists who had sought to cleanse the Islamic "Tradition with a capital $T$ ' of spurious traditions and 'blameworthy innovations' since the twelfth century. ${ }^{71}$ In a more direct way, they were also the product of at least a century of 'orthodoxizing' moves by the Ottoman learned establishment and the imperial state. As we have seen above, some early-sixteenth-century Ottoman scholars such as Ḥalabī and Ibn Kemâl had also advocated a similarly stringent position on such 'innovations' as the congregational performance of supererogatory prayers, albeit without capturing the imagination of a broader cross-section of the urban populace, as did the Kadızâdelis a century later.

Of course, it is questionable how successful the Kadızâdelis themselves were in the push for disambiguation, and in their effort to cleanse the living practice of Muslims of all bid'ats. For the fact is that even as few middle and high-ranking ulema followed the example of Nushî, Sivâsî or Kâtib Çelebi in putting forth a rationally and historically grounded defence of local customs in the face of Sunni traditionalist objections; when it came to actual practice, it was the defenders of the mutating local customs who carried the day. Just

70 On the growing hegemony of law and legalism at the expense of other discursive traditions in modern Muslim conceptions of Islam and on the consequent withering away of the earlier Islamic 'culture of ambiguity', see Shahab Ahmed, What is Islam? The Importance of Being Islamic (Princeton: Princeton University Press, 2016); Thomas Bauer, Die Kultur der Ambiguität: Eine andere Geschichte des Islams (Berlin: Verlag der Weltreligionen im Insel Verlag, 2011). On the modern tendency to reduce sharia normativity to legal judgments, see Johansen, "Die sündige, gesunde Amme", passim.

71 Jonathan Berkey, "Tradition, Innovation and the Social Construction of Knowledge in the Medieval Near East", $P P 146$ (1995), 38-65; Brown, "Even If It's Not True It's True", 1-52. 
as coffeehouses, smoking and the various forms of Sufi music and dance survived the bans of the imperial state and the sermonizing of the preachers, so did the congregational performance of the Raghāib, Barāat and Qadr prayers survive the objections and bickering of the Sunni vigilantes and their lay supporters, and continued to provide vast numbers of Muslim mosque-goers with an important platform for piety and sociability for centuries to come.

\section{Appendix}

\section{Excerpt from Mebâhisü's-Salât, $153 a-154 b$}

İy mü'minler kaçankim bir mes'ele bilinmese ve yahud ol mes'elede 'ulemâ ihtilâf itse esahh-ı akvâl bilmek içün fetvâ çıarurlar ve anuñla 'amel iderler. Biñ otuz dört senesinde Mısr-ı Kâhirede nâfile namâzlar hakkında ihtilâf vâki ${ }^{72}$ olmagın bu 'abd-ı fakîr ilâ rahmeti rabbihi'l-kadîr istiftâ eyledüm. Sûret-i fetvâ budur.

'Âlim-i muhakkık ve hibr-i³ müdakkik ve fâzıl-ı kâmil (153b) ve zâhid-i âmil ve Ebû Yûsuf-ı sânî 'Abdü'l-Kerîm es-Sivâsî hazretleri cevâb virüp buyurur ki:

"El-hamdü lillâhi esahhu'l-akvâl ellezî edînu Allâhe Téâlâ bihi 'ademu'l-itirâzi 'alấl-'âbidi fi hâzâ. 'Avâm-ı nâs[ı] men' câiz degüldür salât-ı Regâiibden ve salât-ı Kadirden. Ammâ İbn 'Abbâs hazretlerinüñ mescid-i Resûlullâhda halka ile zikr idenleri cirîd ile darb idüp mescidden ihrâc itmesi ol evvel zamânda idi. Ve ol zamânda kahve içilmezdi ve duhân içilmezdi ve câmi'lerde kanâdîl asılmazdı ve mumlar yanmazdı, tegannî vü terennüm nâs beyninde yok idi ve mesâlih-i müslimîn nâ-ehile virilmezdi ve 'avâm-ı ceheleye menâsıb-ı 'ulemâ virilmezlerdi ve cühelâi re îs itmezlerdi." Ba'de eyitdi: "Kaçankim 'avâm-ı nâs çarşularda ve bâzâr(154a)larda zikr ider görseyidiñiz ve namâzı kerâhatle kılur görseyidiñüz. Fî zamâninâ men cầiz degüldür." Sümme kâle: "Sübhânallâh, el-'acebu kulle'l-'acebi. Hürmet[i] delîl-i kat'î ile sâbit olanı söylemeyüp sükūt iderler. Zinâ ve livâtadan ve şurb-ı hamr ve şurb-ı duhândan men itmezler ve tavla ve satrancdan men 'itmezler. Muhassal-ı kelâm fî zamâninâ halkı 'ibâdâtdan men' cầiz olmaz, zîrâ ahkâm-ı şer'iyye tegayyür-i zamânla mütegayyir olur. Ve eger ol gicelerde meâbid-i ilâhî[yi] kaparsak, ya’nî câmi'ler ve mescidler kapusın kaparsak meấbid-i şeyâtîn kapuları açukdur, ya'nî kahvehâneler ve bozahâneler ve meyhâneler ve bâbülhâneler açukdur, ekser halk anda giderler ve fisk iderler. Halkuñ sulehâ nâmında olanları (154b)

72 In the manuscript this sentence actually reads as "vâki" oldı olmagın".

73 In the manuscript, this word is actually written as "hayr". 
ednâ mertebe kahvehâneye girerler ve giybet ü mesâvî iderler ve duhân içerler ne'ûzu billâhi teâlâ. Kaçankim müftî halkı bu beliyyelerde görse ehven-i beliyyeteyn ile fetvâ virmek gerekdür ve ehven-i beliyyeteyn câmileri ve mescidleri ta'mîr itmekdür, anda bir zarar varsa dahî." Sümme kâle: "İy câhil fî zamâninâ kerâhatden hâlis hiçbir 'ibâdet bulunur mı? Ol sen didügüñ sahâbe ve tâbi în ve tâbi'-i tâbi în zamânı idi. Mezheb-i mu'temed budur." İntehâ fetvâ 'Abdül-Kerîmi's-Sivâsî.

\section{English Translation}

$O$ believers, whenever [the religio-legal status of] a matter is unknown or whenever the ulema disagree on [the religio-legal status of] a matter, to reach the soundest opinion, they seek a fatwa and act in accordance with it. In the year $1034(1624 / 5 \mathrm{CE})$, when there was a dispute about supererogatory prayers, this slave, this poor one in need of the mercy of God Almighty, sought a fatwa about it. This is the copy of the fatwa:

The verifying scholar, meticulous man of religion, perfected man of virtue, practising ascetic, and a second Ebû Yûsuf, 'Abdülkerîm es-Sivâsî, has answered as follows:

Praise be to God! The soundest of opinions, about which I submit to God Almighty, is not interfering with the worshipper on this matter. It is not permissible to prohibit the common folk from [the congregational performance of] the prayers of Regaib and Kadir. It was in the bygone times that Ibn 'Abbās beat with a stick those who formed a circle and performed zikr in the mosque of the Messenger of God and expelled them from the mosque. In that age, people did not drink coffee or smoke tobacco; mosques were not illuminated with oil lamps and candles; people did not even know of singing and humming; the affairs of the Muslims were not given to the incapable, and the positions of the ulema were not given to the ignorant among the commoners, and they did not appoint the ignorant as leaders." Then he said: [In that bygone time], you could never see the commoners among the people perform zikr in shops and in the marketplace or make blameworthy blunders while performing their ritual prayers. In our time, it is not permissible to prohibit [the congregational performance of the supererogatory prayers of Regaib and Kadir]. Then he said: Praise be to God! This is a most wondrous thing: They keep quiet about those matters that are prohibited by incontrovertible proofs [and they make objections to those that are not]. They do not try to prevent people from committing adultery and sodomy, drinking alcohol and smoking tobacco, or playing backgammon and chess. In short, it cannot be permissible in our time to prevent the people from performing acts 
of worship, because legal judgments change with the changing times. If on those nights we close down the divine temples - namely, mosques and masjids, the temples of Satan - namely, coffeehouses, boza stalls, wine-taverns and brothels [literally, Houses of Babel], will be still open; and most people will go to them and engage in mischief. Even the people who are deemed to be righteous at the very least go to coffeehouses, where they talk behind others and smoke. We seek refuge in God Almighty! When the jurisconsult finds the people to be in a state of such affliction, he should rule for the lesser of the two afflictions and the lesser affliction is to support [going to] mosques and masjids, even if there is some harm in that. Then he said: $\mathrm{O}$ ignorant one, is there any worship in our own time that is free of abomination? That which you speak about was true for the time of the Companions, Successors and Successors of the Successors. This is the trusted path. The fatwa of 'Abdülkerîm es-Sivâsî ends.

\section{Note on Transcription}

All Turkish names and titles, including Arabic citations in Turkish texts, have been rendered according to a simplified form of Turkish transcription. Arabic titles and the names of authors who wrote exclusively in Arabic have been transcribed according to Brill's transliteration system for Arabic. Terms shared by Arabic and Turkish speakers have been rendered according to the conventions of the language used in the specific context discussed in this chapter.

\section{Acknowledgements}

This chapter is dedicated to Professor Metin Kunt as an expression of gratitude for his exemplary scholarship. It is based on research funded by the European Research Council under the European Union's Seventh Framework Programme (FP/2015-2020)/ERC Grant Agreement 648498, "The Fashioning of a Sunni Orthodoxy and the Entangled Histories of Confession-Building in the Ottoman Empire, 15th-17th Centuries". I would like to thank Ahmet Kayl, Çiğdem Kafesçioğlu, Evren Sünnetçioğlu, Guy Burak, Tijana Krstić and Yavuz Aykan as well as the editors of this volume for their insightful comments and criticisms. Naturally, I remain solely responsible for any mistakes that this chapter may contain. 


\section{Bibliography}

\section{Unpublished Primary Sources}

Gazzîzâde Abdüllatif. Menâkıb-ı Gazzî. MS 1042. Orhan, Bursa Eski Yazma ve Basma Eserler Kütüphanesi.

Kadızâde Mehmed. [Untitled treatise]. ms 5563, 44b-47b. Yazma Bağışlar, Süleymaniye Kütüphanesi.

Kadızâde Mehmed. [Untitled Treatise], MS TY 3529, fol. 116b-121a, Türkçe Yazmalar. İstanbul Üniversitesi Kütüphanesi.

Nushî el-Nâsshî/Mustafa b. Hamza b. İbrahim b. Veliyüddin. al-Hayāt Sharh Shurūt al-Ṣalāt, Ms 971, 1a-137a. Hacı Mahmud Efendi, Süleymaniye Kütüphanesi.

Nushî el-Nâshî/Mustafa b. Hamza b. İbrahim b. Veliyüddin. Mebhas-ı Îmân. Ms 5563, 59a-137a. Yazma Bağışlar, Süleymaniye Kütüphanesi.

Nushî el-Nâshhi/Mustafa b. Hamza b. İbrahim b. Veliyüddin. Mebâhisü’s-Salât. Ms 948. Hacı Mahmud Efendi, Süleymaniye Kütüphanesi.

Râkım İbrahim. Vâkı ât-ı Pîr-i Rûşen. Ms 79o. İzmir, Süleymaniye Kütüphanesi.

Sivâsî, Receb. Necmü'l-Hüdâ fì Menâkıbişs-Seyh Şemseddîn Ebiss-Senâ. Ms 694/2. Lala İsmail, Süleymaniye Kütüphanesi.

Sun'ullâh Efendi. Fetâvâa-yi Sun'ullâh Efendi. MS 502. Hasan Hüsnü Paşa, Süleymaniye Kütüphanesi.

Vanî Mehmed. Muhyı̂ss-Sünnet Mümitüll-Bid'at. Ms 663. Kasidecizade. Süleymaniye Kütüphanesi.

\section{Published Primary Sources}

el-Akhisarî, Ahmed. Against Smoking:An Ottoman Manifesto, edited and translated by Yahya Michot. Leicestershire: Kube Publishing, 2010.

Birgivî Mehmed. Tarîkat-ı Muhammediyye, edited by Muhammed Hüsnî Mustafâ, Mehmet Fatih Güney and A. Faruk Beşikçi. Istanbul: Kalem Yayınevi, 2004.

Birgivî Mehmed.Jalā’al-Qulūb, edited by 'Āmir Sa'īd al-Zībārī. Beirut, 1995.

Ebussuûd. Şeyhülislâm Ebussuûd Efendi Fetvaları Işığında 16. Asır Türk Hayatı, edited by Ertuğrul Düzdağ. Istanbul: Enderun Kitabevi, 1983 .

Ḥalabī, İbrahim. Halabī Kabìr. Istanbul: Arif Efendi Matbaası, 1325/19o7-8.

Ḥalabī, İbrahim. Tam Kayıtlı Halebî̀-i Sagîr ve Tercemesi (Taharet ve Namaz Bölümleri), translated by Hasan Ege. Istanbul: Salah Bilici Kitabevi, 1982.

İbn Kemal. Şeyhülislâm İbn Kemal'in Fetvaları Işı̆̆ında Kanûnî Devrinde Osmanlida Hukukî Hayat. Edited by Ahmet İnanır. Istanbul: Osmanlı Araştırmaları Vakfı, 2011. İsmâil Hakkı Bursevî. Kitâbünn-Netîce: Bursevînin Vâridatı ve Şerhleri, edited by Ali Naml.. Istanbul, 2019. 
Jār Allāh Muḥammad b. Fahd. Nukhbat Bahjat al-Zamān bi-Imārat Makka li-Mulk Ban̄̄ 'Uthmān, edited by Qays Kāẓim al-Janabī. Beirut: Dār al-Kutub al-Ilmiyya, 2010.

Katib Çelebi. The Balance of Truth, edited and translated by Geoffrey L. Lewis. London: George Allen and Unwin Ltd, 1957.

[Mehmed II, 'Fatih']. Fatih Sultan Mehmet Vakfiyeleri. 3 vols. Istanbul: T.C. Başbakanlık Vakıflar Genel Müdürlüğü ve Çamlıca Kültür ve Yardım Vakfi, 2003.

Mustafa Naîmâ Efendi. Târih-iNa îmâ (Ravzatül-Hüseyn fî Hulâsati Ahbâri'l-Hâfikayn). Edited by Mehmet İpşirli, 4 vols. Ankara: TTK, 2007.

Öz, Tahsin (ed.) Zwei Stiftungsurkunden des Sultans Mehmed II. Fatih. Istanbul: Devlet Matbaası, 1935 .

al-Qārī, 'Alī. Al-Asrār al-Marfū'at fì l-Akhbār al-Mawḍ̂̄'at, edited by Muhammad b. Lutfī Sabbāgh. Beirut: Dār al-Amāna, 1971.

Schweigger, Salomon. Einnewe Reyssbeschreibung auss Teutschlandnach Constantinopel und Jerusalem. Nurnberg: Lantzenberger, 16o8; reprinted. Graz: Akademische Druck- u. Verlagsanstalt, 1964.

Selânikî Mustafa. Tarih-i Selânikî, edited by Mehmet İpşirli, 2 vols. Istanbul: Edebiyat Fakültesi, 1989 .

Sevim, Sezai and Hasan Basri Öcalan (eds). Osmanlı Kuruluş Dönemi Bursa Vakftyeleri. Bursa: Osmangazi Belediyesi, 2010.

Sivasî, Receb. Hidâyet Yıldızı: Şems-ed-dîn-i Sivâsî Hazretlerinin Menkıbeleri, translated by Hüseyin Şemsi Güneren and edited by Fatih Güneren. Istanbul, n.d.

Uzunçarşıll, İsmail Hakkı. "Niğde'de Karamanoğlu Ali Bey Vakfiyesi”, Vakıflar Dergisi 2 (1942), 45-69.

\section{Secondary Sources}

Abou-El-Haj, Rifa'at 'Ali. Formation of the Modern State: The Ottoman Empire, Sixteenth to Eighteenth Centuries. New York: State University of New York Press, 1991.

Ahmed, Shahab. What is Islam? The Importance of Being Islamic. Princeton: Princeton University Press, 2016.

Aslan, Halide. "Osmanlı İmparatorluğu'nda Mübarek Gün ve Gecelerden Kandiller”. İslam San'at, Tarih, Edebiyat ve Mûsikîsi Dergisi 7 (13) 2009, 199-231.

Baer, Marc David. Honored by the Glory of Islam: Conversion and Conquest in Ottoman Europe. Oxford: Oxford University Press, 2008.

Bauer, Thomas. Die Kultur der Ambiguität: Eine andere Geschichte des Islams. Berlin: Verlag der Weltreligionen im Insel Verlag, 2011.

Berkey, Jonathan. "Tradition, Innovation and the Social Construction of Knowledge in the Medieval Near East". Past and Present 146 (1995), 38-65.

Birgivî Mehmed, Rasā’il al-Birkawī, edited by Aḥmad Hādī al-Qașṣār. Beirut: Dār al-Kutub al-'Ilmìya, 2011. 
Bori, Caterina. "Transregional Spaces of Reading and Reception". The Muslim World 108 (1) 2018, 87-123.

Brown, Jonathan. "Even If It's Not True It's True: Using Unreliable Hadīths in Sunni Islam," Islamic Law and Society 18 (2011), 1-52.

Burak, Guy. "Faith, Law and Empire in the Ottoman Age of Confessionalization (Fifteenth-Seventeenth Centuries): The Case of 'Renewal of Faith'. Mediterranean Historical Review 28 (1) 2013, 1-23.

Burak, Guy. "The Second Formation of Islamic Law: The Post-Mongol Context of the Ottoman Adoption of a School of Law". Comparative Studies in Society and History 55 (3) 2013, 579-6o2.

Burak, Guy. The Second Formation of Islamic Law: The Hanafi School in the Early Modern Ottoman Empire. Cambridge: Cambridge University Press, 2015.

Buzov, Snjezana. "The Lawgiver and His Lawmakers: The Role of Legal Discourse in the Change of Ottoman Legal Culture." Ph.D. dissertation, Chicago University, 2005.

Canbakal, Hülya. "Vows as Contract in Ottoman Public Life (17th-18th Centuries)". Islamic Law and Society, 18 (1) 2011, 85-115.

Cici, Recep. Bir Osmanlı Fakihi: Âlim Muhammed b. Hamza’nın Fıkıh Risâleleri. Bursa: Emin Yayınları, [2006].

Cook, Michael. Commanding Right and Forbidding Wrong in Islamic Thought. Cambridge: Cambridge University Press, 2000.

Curry, John J. “'The Meeting of the Two Sultans': Three Sufi Mystics Negotiate with the Court of Murād III". In John J. Curry and Erik S. Ohlander (eds). Sufism and Society: Arrangements of the Mystical in the Muslim World, 1200-1800. London: Routledge, 2012, 223-42.

Çavuşoğlu, Semiramis. "The Kăạīzādeli Movement: An Attempt of Şerīat-minded Reform in the Ottoman Empire". Ph.D. dissertation, Princeton University, 1990.

Dönmez, Mustafa İsmail. “Kuşadalı Mustafa bin Hamza ve 'Netâicül-EfkârfiŞerhi'l-İzhâr' Adlı Eseri (İnceleme ve Tahkik)”. Ph.D. dissertation, Marmara Üniversitesi, 2013.

Fadel, Mohammed. "The Social Logic of Taqlìd and the Rise of the Mukhtașar". Islamic Law and Society 3 (2) 1996, 193-233.

Felek, Özgen. "(Re)creating Image and Identity: Dreams and Visions as a Means of Murād III's Self-Fashioning”. In Özgen Felek and Alexander D. Knysh (eds). Dreams and Visions in Islamic Societies Dreams and Visions in Islamic Societies. Albany: State University of New York Press, 2012, 249-72.

Franke, Patrick. "The Ego of the Mullah: Strategies of Self-Representation in the Works of the Meccan Scholar 'Alī al-Qārī (d.16o6)". In Ralf Elger and Yavuz Köse (eds), Many Ways of Speaking About the Self: Middle Eastern Ego-Documents in Arabic, Persian, and Turkish (14th-2oth century). Wiesbaden: Harrassowitz Verlag, 2010, $185^{-200 .}$ 
Gel, Mehmet. "XVI. Yüzyılın İlk Yarısında Osmanlı Toplumunun Dinî Meselelerine Muhalif Bir Yaklaşım: Şeyhülislam Çivizâde Muhyiddin Mehmed Efendi ve Fikirleri Üzerine Bir İnceleme". Ph.D. thesis, Gazi Üniversitesi, 2010.

Gerber, Haim. State, Society, and Law in Islam: Ottoman Law in Comparative Perspective. Albany: State University of New York Press, 1994.

Grehan, James. “Smoking and 'Early Modern' Sociability: The Great Tobacco Debate in the Ottoman Middle East (Seventeenth to Eighteenth Centuries)". American Historical Review 111 (December 2006), 1352-77.

Gündoğdu, Cengiz. Bir Türk Mutasavvıfı Abdülmecîd Sivâsî̀ (971/1563-1049/1639): Hayatı, Eserlerive Tasavvufi Görüşleri. Ankara: Kültür Bakanlığı, 2000.

Cengiz Gündoğdu. "Sivâsî, Abdülmecid". DIA, vol. 37. Istanbul, 2009.

Güven, Mustafa Salim (ed.) "Çeşitli Yönleriyle Azîz Mahmûd Hüdâyî̀nin Mektupları”. MA thesis, Marmara Üniversitesi, 1992.

Hallaq, Wael B. "Was the Gate of Ijtihad Closed?" International Journal of Middle East Studies 16 (1984), 3-41.

Hallaq, Wael B. "From Fatwās to Furū : Growth and Change in Islamic Substantive Law". Islamic Law and Society 1 (1) 1994, 29-65.

Hallaq, Wael B. A History of Islamic Legal Theories. Cambridge: Cambridge University Press, 1997 .

Hallaq, Wael B. "The Jurisconsult, the Author-Jurist and Legal Change". In idem. Authority, Continuity and Change in Islamic Law. Cambridge: Cambridge University Press, 2001, 166-235.

Hattox, Ralph. Coffee and Coffeehouses: The Origins of a Social Beverage in the Medieval Near East. Seattle: University of Washington Press, 1985.

Imber, Colin. Ebu's-Su'ud: The Islamic Legal Tradition. Stanford: Stanford University Press, 1997 .

Ivanyi, Katharina Anna. "Virtue, Piety and the Law: A Study of Birgivī Mehmed Efendi's al-Tarīqat al-Muhammadiyya”. Ph.D. dissertation, Princeton University, 2012.

Ivanyi, Katharina Anna. “And the Question of Lands is Very Confusing': Birgivî Mehmed Efendi (d.981/1573) on Land Tenure and Taxation". In Marinos Sariyannis (ed.) Political Thought and Practice in the Ottoman Empire, Halcyon Days in Crete $I X$, a symposium held in Rethymno, 9-11 January 2015. Rethymno: Crete University Press, 2019, 137-47.

Johansen, Baber. Islamic Law on Land Tax and Rent: The Peasants' Loss of Property Rights as Interpreted in the Hanafite Legal Literature of the Mamluk and Ottoman Periods. London: Croom Helm, 1988.

Johansen, Baber. "Die sündige, gesunde Amme: Moral und gesetzliche Bestimmung $($ Hukm) im Islamischen Recht”, in idem, Contingency in a Sacred Law: Legal and Ethical Norms in the Muslim Fiqh (Leiden: Brill, 1999), 172-88 
Johansen, Baber. Contingency in a Sacred Law: Legal and Ethical Norms in the Muslim Fiqh. Leiden: Brill, 1999 .

Kafadar, Cemal. "How Dark is the History of the Night, How Black the Coffee and How Bitter the Tale of Love: The Measure of Leisure and Pleasure in Early Modern Istanbul". In Arzu Öztürkmen and Evelyn Birge Vitz (eds), Medieval and Early Modern Performance in the Eastern Mediterranean. Turnhout: Brepols, 2014, 243-69.

Kafesçioğlu, Çiğdem. Constantinopolis/Istanbul: Cultural Encounter, Imperial Vision, and the Construction of the Ottoman Capital. University Park, PA: Pennsylvania State University Press, 2009.

Kara, İhsan. "İsmail Hakkı Bursevi'nin Tuhfe-i Hasekiyyesi (3. Bölüm)," MA thesis, Marmara Üniversitesi, 1997.

Karadaş, Cağfer. “Ali el-Kârî’nin Akaide Dair Eserleri ve Bazı İtikadi Görüşleri”. MA thesis, Marmara Üniversitesi, 1991.

Karadaş, Cağfer. “Ali el-Kârî̀nin Hayatı, Selef Akîdesine Dönüş Çabası ve Eserleri”. Uludağ Üniversitesi İlahiyat Fakültesi Dergisi 5 (5) 1993, 287-99.

Katz, Marion Holmes. "The 'Corruption of the Times' and the Mutability of the Shari'a”. Cardozo Law Review 28 (1) 2006, 171-85.

Katz, Marion Holmes. The Birth of the Prophet Muhammad: Devotional piety in Sunni Islam. Abingdon: Routledge, 2007.

Katz, Marion Holmes. Prayer in Islamic Thought and Practice. Cambridge: Cambridge University Press, 2013.

Kaylı, Ahmet. "A Critical Study of Birgivî Mehmed Efendi's Works and their Dissemination in Manuscript Form”. MA thesis, Boğaziçi Üniversitesi, 2010.

Kenan, Seyfi. “Doğruyu Dengede Tutmak: Mîzânüll-Hak Çerçevesinde Kâtip Çelebi'nin Bilgi ve Eğitim Anlayışı”. In Said Öztürk (ed.) Vefatının 350. Yılında Kâtip Çelebi. Istanbul: İstanbul Büyükşehir Belediyesi, 2007, 87-91.

Köse, Ömer Faruk. "The Fatwa Collection of an Ottoman Provincial Mufti, Vani Mehmed Efendi (d.1685)”. MA thesis, Boğaziçi Üniversitesi, 2015.

Krstić, Tijana. Contested Conversions to Islam: Narratives of Religious Change in the Ottoman Empire. Stanford: Stanford University Press, 2011.

Le Gall, Dina. "Kadızadelis, Nakşbendis, and Intra-Sufi Diatribe in Seventeenth-Century Istanbul". The Turkish Studies Association Journal 28 (1-2) 2004, 1-28.

Le Gall, Dina. A Culture of Sufism: Naqshbandīs in the Ottoman World, 1450-1700. Albany, NY: State University of New York Press, 2005.

Mandaville, Jon E. "Usurious Piety in the Ottoman Empire:The Cash Waqf Controversy". International Journal of Middle East Studies 10 (1979), 289-308.

Martı, Huriye. Birgivî Mehmed Efendi. Ankara: Türkiye Diyanet Vakfı Yayınları, 2008.

Melchert, Christopher. The Formation of the Sunni Schools of Law, gth-1oth Centuries CE. Leiden: Brill, 1997. 
Meshal, Reem. "Antagonistic Sharías and the Construction of Orthodoxy in Sixteenth-Century Ottoman Cairo." Journal of Islamic Studies 21 (2) 2010, 183-212.

Mundy, Martha and Richard Saumarez Smith. Governing Property, Making the Modern State: Law, Administration and Production in Ottoman Syria. London: I. B. Tauris, 2007.

Namlı, Ali. İsmâil Hakkı Bursevî: Hayatı, Eserleri, Tarikat Anlayışı. Istanbul: İnsan Yayınları, 2001.

Necipoğlu, Gülru. The Age of Sinan: Architectural Culture in the Ottoman Empire. Princeton: Princeton University Press, 2005.

Ocak, Ahmet Yaşar. "XVII. Yüzyılda Osmanlı İmparatorluğu’nda Dinde Tasfiye (Püritanizm) Teşebbüslerine Bir Bakış: Kadızadeliler Hareketi”. Türk Kültürü Araştırmaları 1-2 (1983), 208-25.

Okic, M. Tayyib. "Çeşitli Dillerde Mevlitler ve Süleyman Çelebi'nin Mevlid'inin Çevirileri”. Atatürk Üniversitesi İlahiyat Fakültesi Dergisi 1 (1976), 17-78.

Pfeifer, Helen. "Encounter After the Conquest: Scholarly Gatherings in 16th-century Ottoman Damascus." International Journal of Middle East Studies 47 (2015), 219-39.

Radtke, Bernd. "Birgiwīs Ṭarīqa Muḥammadiyya: Einige Bemerkungen und Überlegungen". Journal of Turkish Studies 26 (1) 2002. This same article also appears in Jan Schmidt (ed.), Essays in Honour of Barbara Flemming. Cambridge, MA: Department of Near Eastern Languages and Civilizations, Harvard University, 2002, 159-174.

Rafeq, Abdul Karim. "The Syrian 'Ulamā', Ottoman Law, and Islamic Sharī‘a”. Turcica 26 (1994), 9-32.

Rafeq, Abdul Karim. "The Opposition of the Azhar 'Ulamā' to Ottoman Laws and its Significance in the History of Ottoman Egypt" In Brigitte Marino (ed.) Études sur les villes du Proche-Orient XVI et XIX ${ }^{e}$ siècle: Hommage à André Raymond. Damascus: Institut français d'études arabes de Damas, 2001, 43-54.

Reinhart, Kevin. "When Women Went to Mosques: al-Aydini on the Duration of Assessments". In Muhammad Khalid Masud, Brinkley Messick and David S. Powers (eds). Islamic Legal Interpretation: Muftis and Their Fatwas. Cambridge, MA: Harvard University Press, 1996, 116-28.

Repp, Richard C. The Müfti of Istanbul: A Study in the Development of the Ottoman Learned Hierarchy. London: Ithaca Press, 1986.

El-Rouayheb, Khaled. "From Ibn Hajar al-Haytamī (d.1566) to Khayr al-Dīn al-Ālūsī (d.1899): Changing Views of Ibn Taymiyya amongst Sunni Islamic Scholars". In S. Ahmed and Y. Rapoport (eds). Ibn Taymiyya and His Times. Oxford: Oxford University Press, 2010, 69-318.

El-Rouayheb, Khaled. Islamic Intellectual History in the Seventeenth Century: Scholarly Currents in the Ottoman Empire and the Maghrib. Cambridge: Cambridge University Press, 2015. 
Sariyannis, Marinos. "The Kadızadeli Movement as a Social Phenomenon: The Rise of a 'Mercantile Ethic'?" In Antonis Anastasopoulos (ed.) Political Initiatives from the Bottom up' in the Ottoman Empire, Halcyon Days in Crete VII, 9-11 Jan. 2009. Rethymno: Crete University Press, 2012, 263-89.

Sariyannis, Marinos. "Ruler and State, State and Society in Ottoman Political Thought". Turkish Historical Review 4 (2013), 83-117.

Schlegell, Barbara Rosenow von. "Sufism in the Ottoman Arab World: Shaykh 'Abd al-Ghanī al-Nābulusī (d. 1143/1731)". Ph.D. dissertation University of California, Berkeley, 1997.

El-Shamsy, Ahmed. The Canonization of Islamic Law: A Social and Intellectual History. New York: Cambridge University Press, 2013.

Sheikh, Mustapha. Ottoman Puritanism and its Discontents: Aḥmad al-Rumī al-Aqhișārē and the Qādizādelis. Oxford: Oxford University Press, 2016.

Sheikh, Mustapha. "Taymiyyan Influences in an Ottoman-Hanafì Milieu: The Case of Aḥmad al-Rūmī al-Aqhișān̄̄". The Royal Asiatic Society 3 (2014), 1-20.

Soyal, Fikret. "Celâleddin ed-Devvânî’nin Firavun'un İmânı Konusundaki Görüşleri ve Ali el-Kârî'nin Eleştirisi”. MA thesis, Istanbul Üniversitesi, 2004.

Talmon-Heller, Daniella. Islamic Piety in Medieval Syria: Mosques, Sermons and Cemeteries under the Zangids and Ayyūbids (1146-1260). Leiden: Brill, 2007.

Talmon-Heller, Daniella and Raquel Ukeles. "The Lure of a Controversial Prayer: Șalāt al-Raghāib (The Prayer of Great Rewards) in Medieval Arabic Texts and from a Socio-Legal Perspective". Der Islam 89 (2) 2012, 141-66.

Terzioğlu, Derin. "Sunna-minded Sufi Preachers in Service of the Ottoman State: The Nașịhatnāme of Hasan Addressed to Murad IV". Archivum Ottomanicum 27 (2010), 241-312.

Terzioğlu, Derin. "Where 'ilm-i Hâal Meets Catechism: Islamic Manuals of Religious Instruction in the Ottoman Empire in the Age of Confessionalization". Past and Present 220 (2013), 79-114.

Terzioğlu, Derin. "Power, Patronage, and Confessionalism: Ottoman Politics as Seen through the Eyes of a Crimean Suf, 1580-1593". In Marinos Sariyannis (ed.), Political Thought and Practice in the Ottoman Empire: Halcyon Days in Crete IX, A symposium held in Rethymno, 9-11 January 2015. Rethymno: Crete University Press, 2019, 149-86.

Terzioğlu, Derin. "Ibn Taymiyya, al-Siyāsa al-Shar'iyya and the Early Modern Ottomans". In Tijana Krstić and Derin Terzioğlu (eds). Historicizing Sunni Islam in the Ottoman Empire, c.1450-c.175o. Leiden: Brill, 2020.

Tezcan, Baki. The Second Ottoman Empire: Political and Social Transformation in the Early Modern World. Cambridge: Cambridge University Press, 2012.

Tezcan, Baki. "The Portrait of the Preacher as a Young Man: Two Autobiographical Letters by Kadızade Mehmed from the Early Seventeenth Century". In Marinos 
Sariyannis (ed.) Political Thought and Practice in the Ottoman Empire, Halcyon Days in Crete Ix: A Symposium Held in Rethymno, 9-11 January 2015. Rethymno: Crete University Press, 2019, 187-249.

Tezcan, Baki. "A Canon of Disenchantment: Birgivi, Rumi and Kadızade". In idem, A Gift for the Turks: Studies on Islam and its Early Modern Transformation in the Ottoman Empire. Istanbul: IsIs Press, forthcoming 2020.

Tuşalp Atiyas, E. Ekin. “The 'Sunna-Minded' Trend”. In Marinos Sariyannis (ed.) A History of Ottoman Political Thought up to the Early Nineteenth Century. Leiden: Brill, 2019, 233-78.

Yüksel, Emrullah. Mehmed Birgivînin (929-981/1523-1573) Dinî ve Siyasî Görüşleri. Ankara: Türkiye Diyanet Vakfi Yayınları, 2011.

Zilfi, Madeline C. "The Kadızadelis: Discordant Revivalism in Seventeenth-Century Istanbul". Journal of Near Eastern Studies 4 (1986), 251-71.

Zilf, Madeline C. The Politics of Piety: The Ottoman Ulema in the Postclassical Age (1600-1800). Minneapolis: Bibliotheca Islamica, 1988. 